\title{
FINAL REPORT BWR Drywell Debris Transport Phenomena Identification and Ranking Tables (PIRTs)
}

\author{
Gary E. Wilson (INEEL, Project Coordinator) \\ Brent E. Boyack (LANL) \\ Mark T. Leonard (ITSC) \\ Ken A. Williams (FSSI) \\ Lothar T. Wolf (UMCP)
}

Published September 1997

Idaho National Engineering and Environmental Laboratory

Nuclear Systems Analysis Technologies Department

Lockheed Martin Idaho Technologies Company

Idaho Falls, Idaho $\mathbf{8 3 4 1 5}$

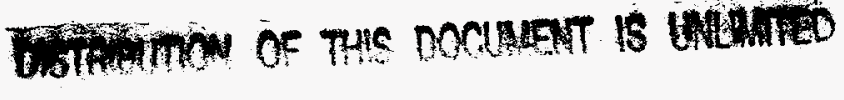

Prepared for the

Division of Engineering Technology

Office of Nuclear Regulatory Research

U. S. Nuclear Regulatory Commission

Washington, D.C. 20555

Under DOE Idaho Operations Office

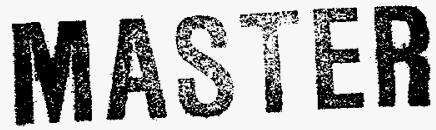

Contract No. DE-AC07-94ID13223 


\section{DISCLAIMER}

This report was prepared as an account of work sponsored by an agency of the United States Government. Neither the United States Government nor any agency thereof, nor any of their employees, makes any wartanty, express or implied, or assumes any legal liability or responsibility for the accuracy, completeness, or usefulness of any information, apparatus, product, or process disclosed, or represents that its use would not infringe privately owned rights. Reference herein to any specific commercial product, process, or service by trade name, trademark, manufacturer, or otherwise does not necessarily constitute or imply its endorsement, recommendation, or favoring by the United States Government or any agency thereof. The views and opinions of authors expressed herein do not necessarily state or reflect those of the United States Government or any agency thereof. 


\section{DISCLAIMER}

Portions of this document may be illegible electronic image products. Images are produced from the best available original document. 


\begin{abstract}
The Nuclear Regulatory Commission has issued a Regulatory Bulletin and accompanying Regulatory Guide (1.82, Rev. 2) which requires licensees of boiling water reactors to develop a specific plan of action (including hardware backfits, if necessary) to preclude the possibility of early emergency core cooling system strainer blockage following a postulated loss-of-coolantaccident. The postulated mechanism for strainer blockage is destruction of piping insulation in the vicinity of the break and subsequent transport of fragmented insulation to the wetwell. In the absence of more definitive information, the Regulatory Guide recommends that licensees assume a drywell debris transport fraction of 1.0. Accordingly, the Nuclear Regulatory Commission initiated research focused toward developing a technical basis to provide insights useful to regulatory oversight of licensee submittals associated with resolution of the postulated strainer blockage issue. Part of this program was directed towards experimental and analytical research leading to a more realistic specification of the debris transport through the drywell to the wetwell. To help focus this development into a cost effective effort, a panel, with broad based knowledge and experience, was formed to address the relative importance of the various phenomena that can be expected in plant response to postulated accidents that may produce strainer blockage. The resulting phenomena identification and ranking tables reported herein were used to help guide research. The phenomena occurring in boiling water reactors drywells was the specific focus of the panel, although supporting experimental data and calculations of debris transport fractions were considered.
\end{abstract}

FIN No. W6662 - PIRT Evaluation of LOCA Debris Transport Within a BWR Drywell 


\section{Executive Summary}

The NRC has issued a Regulatory Bulletin and accompanying Regulatory Guide (1.82, Rev. 2) which requires licensees of BWRs to develop a specific plan of action (including hardware backfits, if necessary) to preclude the possibility of early ECCS strainer blockage following a postulated LOCA. In the absence of more definitive information, the Regulatory Guide recommends that licensees assume a drywell debris transport fraction of 1.0. Accordingly, the NRC initiated research focused toward developing a technical basis to provide insights useful to regulatory oversight of licensee submittals associated with resolution of the postulated strainer blockage issue. Part of this program was directed toward experimental and analytical research to help determine a more realistic specification of the debris transport through the drywell to the wetwell. To help focus this development, a panel, with broad based knowledge and experience, was formed to apply the PIRT process to the transport of break-generated debris through BWR drywells. The first phase of the PIRT project, executed in April-May 1996, was focused toward timely development of initial PIRTs to guide the on-going research. The second and third phases, executed in August 1996 - February 1997, consisted primarily of panel evaluation of the planned experimental effort, and preliminary experimental results. The fourth phase, completed in July 1997, focused on panel review of the final research results in the context of updating the PIRTs based on the new experimental and analytical evidence. Those findings are the primary subject of this final report.

The PIRTs developed by the panel were used to help guide the experimental and analytical research. The early PIRTs have been updated to reflect the new research results. The highly important phenomena from the updated tables are summarized on the next page by drywell location (component), general phenomena type, and time in the transient (blowdown phase and post blowdown phase). Tables 1 and 2 in the body of the report list the full, and final, PIRTs developed by the panel.

Accident scenario and plant design selections are an important part of the PIRT process. Given the combinations of break locations and containment types, a large number of scenarios are possible. Initially the panel focused on a single break type (high elevation main steam line break), a single containment type (Mark I), and no containment spray. However, obvious differences in phenomena importance in a recirculation line break low in the drywell, and in the other two containment designs, were also identified. Thus, the final PIRTs reported herein address both scenarios and all three containment designs, to the extent allowed by the final experimental and analytical evidence.

In the process of reviewing the new experimental and analytical evidence, the panel formulated several observations regarding the total research program. These "insights" are also documented as part of this report, as a secondary objective of the panel efforts. The more important of these follow immediately below in two main topics: 1) Methodology to synthesize research, and

2) Lessons learned regarding the PIRT process.

1) Methodology to synthesize research results into a basis to judge licensee submittals:

a) The panel believes the structure of the methodology:

- Will provide a rational technical basis for the desired licensing reviews

- Is sufficiently flexible that new evidence and assumptions, related to debris size and distribution, can quickly be accommodated to provide a basis for submittal evaluations not covered at the time this report was issued 
BWR drywell debris transport highly important phenomena

\begin{tabular}{|c|c|c|c|}
\hline$\overline{\text { Component }}$ & $\begin{array}{c}\text { Phenomenon } \\
\text { type }\end{array}$ & Phenomenon & $\begin{array}{l}\text { Highest of the highly } \\
\text { ranked phenomena }\end{array}$ \\
\hline \multicolumn{4}{|c|}{ Blowdown phase } \\
\hline \multirow{4}{*}{$\begin{array}{l}\text { Drywell } \\
\text { open } \\
\text { areas }\end{array}$} & \multirow{3}{*}{$\begin{array}{l}\text { Thermal hydraulic } \\
\text { related }\end{array}$} & Pressure driven flows (bulk flows) & $\sqrt{ }$ \\
\hline & & Localized flow field & $\sqrt{2}$ \\
\hline & & Flashing of break liquid effluent (2) & $\checkmark$ \\
\hline & $\begin{array}{l}\text { Debris transport \& } \\
\text { depletion related }\end{array}$ & Advection/slip & $\checkmark$ \\
\hline \multirow{5}{*}{$\begin{array}{l}\text { Drywell } \\
\text { structures }\end{array}$} & \multirow{2}{*}{$\begin{array}{l}\text { Thermal hydraulic } \\
\text { related }\end{array}$} & Porosity & $\checkmark$ \\
\hline & & Recirculation (streaming) deluge & $\checkmark$ \\
\hline & \multirow[t]{3}{*}{$\begin{array}{l}\text { Debris transport \& } \\
\text { depletion related }\end{array}$} & $\begin{array}{l}\text { Recirculation deluge (streaming) } \\
\text { related transport }\end{array}$ & $\checkmark$ \\
\hline & & Impaction & 7 \\
\hline & & Adhesion & $\checkmark$ \\
\hline \multirow{5}{*}{$\begin{array}{l}\text { Drywell } \\
\text { floor }\end{array}$} & \multirow{3}{*}{$\begin{array}{l}\text { Thermal hydraulic } \\
\text { related }\end{array}$} & Pool formation (2) & $\checkmark$ \\
\hline & & Pool overflow (timing issue this phase) (2) & $\checkmark$ \\
\hline & & Pool flow dynamics 2 & \\
\hline & \multirow{2}{*}{$\begin{array}{l}\text { Debris transport \& } \\
\text { depletion related }\end{array}$} & Pool transport (to/through vent) & $\sqrt{ }$ \\
\hline & & Settling (2) & \\
\hline \multirow{3}{*}{$\begin{array}{l}\text { Drywell } \\
\text { structures }\end{array}$} & & Post-blown down phase & \\
\hline & $\begin{array}{l}\text { Thermal hydraulic } \\
\text { related }\end{array}$ & ECCS deluge & \\
\hline & $\begin{array}{l}\text { Debris transport \& } \\
\text { depletion related }\end{array}$ & ECCS deluge & \\
\hline \multirow{5}{*}{$\begin{array}{l}\text { Drywell } \\
\text { floor }\end{array}$} & \multirow{3}{*}{$\begin{array}{l}\text { Thermal hydraulic } \\
\text { related }\end{array}$} & Pool overflow & \\
\hline & & Pool formation & \\
\hline & & Pool flow dynamics ${ }^{(3)}$ & $\sqrt{ }$ \\
\hline & \multirow{2}{*}{$\begin{array}{l}\text { Debris transport \& } \\
\text { depletion related }\end{array}$} & Pool transport (to/toward vent) & $\sqrt{ }$ \\
\hline & & Settling & \\
\hline
\end{tabular}

Notes: (1) All phenomena listed in the table are of high importance. However, those indicated by a check mark $(\checkmark)$ are the "highest of the high".

(2) Applies only to the recirculation line break.

(3) Applies only in the case of drywell overflow to vent.

b) The panel finds the methodology attractive in that it:

- Clearly delineates important phenomena in the BWR drywell

- Readily incorporates, and links, both experimental and analytical results

- Is comprehensible to engineers having less experience in the subject of interest

c) With respect to the current application of the methodology, the panel perceives the following potential weaknesses [see Section 3.2-3)]:

- The rationale for upper bounds on the transport fraction needs to be strengthened. This perception is related to the the treatment of the upper and lower bounds, and the desirability of additional validation related to the character (size and distribution) of the generated debris. 
- The basis for the applied flow velocities in the ARL and CEESI experiments needs strengthened. That is, their applicability to prototypical plant conditions needs to be more strongly demonstrated by a consistent scaling approach [Section .

- The experimental data base for the behavior (including ECCS erosion) of large debris on gratings is considered incomplete. In some part this is related to the above item.

- The data base for the recirculation line LOCA is considered to be too small given the relative importance of that transient and its consequences.

2) Lessons learned regarding the PIRT process:

a) The generic PIRT process was readily adapted to the needs of the program and proved to be an effective method to organize a highly complex problem into tractable subparts. Consequently, the results were used in planning and conducting the continuing research.

b) Comparison of the final PIRTs with the initial PIRTs tends to further validate the effectiveness of using independent teams, having collective broad based knowledge, early in research programs addressing new problems, as illustrated by the following:

- No new phenomena were identified

- One phenomenon rank moved from moderate to high rank, based on new evidence (i.e., surface wetting during the blowdown phase)

- In two cases the ranks of related phenomenon effects moved from low to high (i.e., ECCS deluge influence on thermal hydraulics and on debris transport during the post-blowdown phase)

- Three phenomenon ranks moved from high importance to highest importance (i.e., pool formation, pool overflow and pool transport to/through the vent during the blowdown phase)

- Although the ranks of several phenomena were increased, the most noticeable trend between the initial and final PIRTs was the decrease in phenomena importance. This validates the built-in rule in the process, that in the absence of evidence, the team is to initially rank phenomena at their highest conceivable rank until further evidence is acquired as to the more realistic rank. 


\section{Acknowledgments}

Several organizations and individuals were most helpful in the PIRT panel efforts. Although the panel was charted for, and carefully maintained, an independent and separate perspective, the panel acknowledges the aid from:

- Aleck Serkiz (NRC-RES), Michael Marshall, Jr. (NRC-RES) and Robert Elliot (NRCNRR) for their help in facilitating the panel's increased understanding of the NRC research and licensing needs and objectives.

- DV Rao and Clint Shaffer (SEA) for their help in the panel's understanding of the experimental and analytical research conducted by SEA and ARL. The panel also acknowledges SEA and all of the associated staff for providing the facilities and other aid for the panel meetings.

Mark T. Leonard (ITSC), one of the listed authors of this report, served on the panel from its inception until October 1996. Because of other responsibilities, Mr. Leonard no longer served on the panel after that time. The remaining panel members acknowledge Mr. Leonard's significant contributions to the early work. 


\section{Contents}

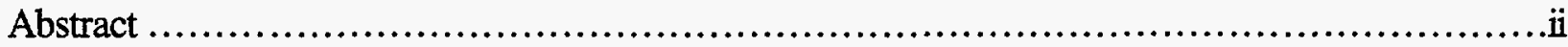

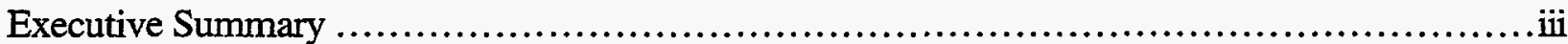

Acknowledgments .......................................................................... vi

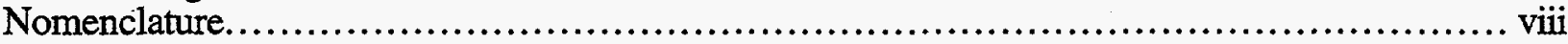

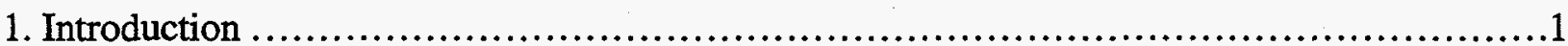

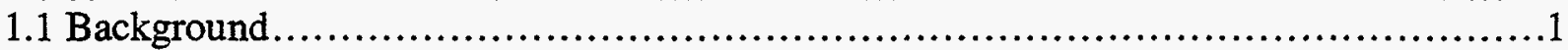

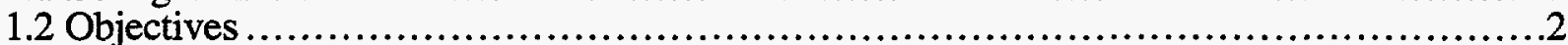

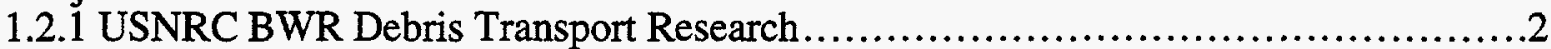

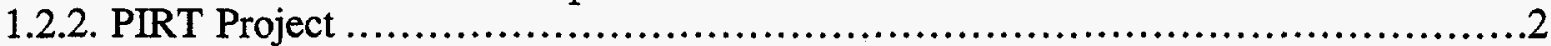

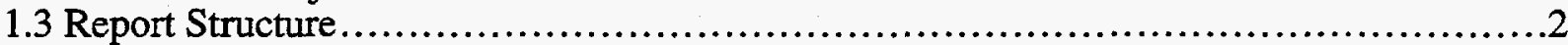

2. BWR Drywell Debris Transport PIRTs.................................................

2.1 PIRT Process Overview....................................................................

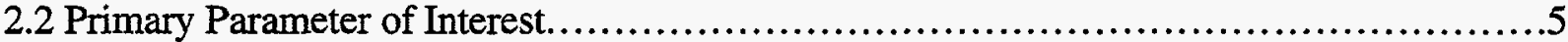

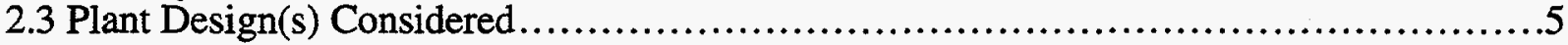

2.4 Accident Scenario(s) Considered........................................................

2.5 Partitioning of Drywell into Components .............................................6

2.6 Partitioning of Scenario into Time Phases ................................................

2.7 System Level Processes..................................................................

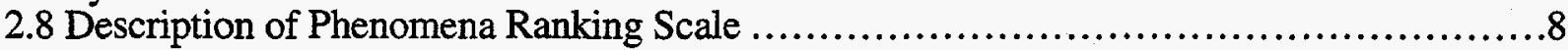

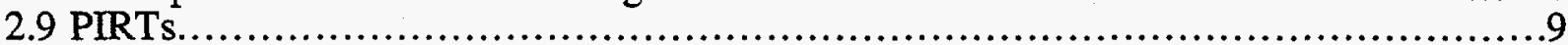

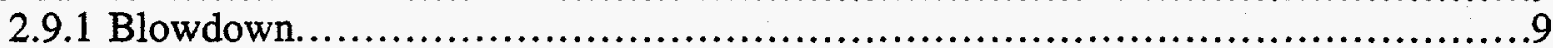

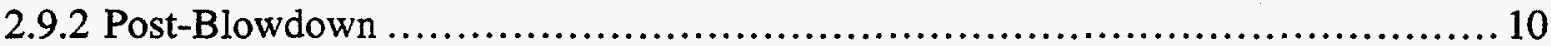

2.9.3 Ranking Summary............................................................ 10

3. Panel Insights Regarding BWR Debris Transport...................................... 15

3.1 PIRT Related Insights ...................................................... 15

3.2 Methodology to Synthesize Research Results Into a Basis to Judge Licensee Submittals .. 16

4. References.

\section{APPENDICES}

Appendix A: Phenomena Descriptions for BWR Debris Transport PIRTs ....................A1 Appendix B: Ranking Rationales for BWR Debris Transport PIRTs............................. 1 Appendix C: Information Base Used in the Application of the PIRT Process Debris .............C1 Transport in a BWR Drywell

\section{FIGURES}

Figure 1. Illustration of typical PIRT process..............................................4

Figure 2. Component partitioning of drywell. ................................................

TABLES

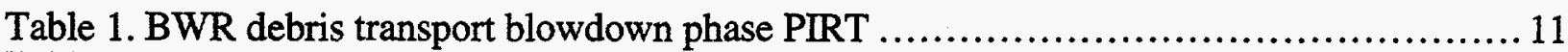

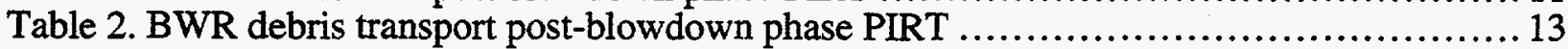

Table 3. Goals and associated success criteria for NRC-NRR's development and................ 15 application of an analysis framework for evaluating debris transport 


\title{
Nomenclature
}

\author{
AHP Analytical Hierarchy Process \\ ARL Alden Research Laboratory, Inc. \\ BWR Boiling Water Reactor \\ BWROG BWR Owner's Group \\ CEESI Colorado Engineering Experimental Station, Inc. \\ CFD Computational Fluid Dynamics \\ DOE US Department of Energy \\ ECCS Emergency Core Cooling Systems \\ FSSI Flow Simulation Services, Inc. \\ INEEL Idaho National Engineering and Environmental Laboratory \\ ITSC Innovative Technology Solutions Corporation \\ LANL Los Alamos National Laboratory \\ LB Large Break \\ LOCA Loss of Coolant Accident \\ MB Medium Break \\ MSLB Main Steam Line Break \\ NPP Nuclear Power Plant \\ NPSH Net Pump Suction Head \\ NRC US Nuclear Regulatory Commission \\ NRR Office of Nuclear Reactor Regulation \\ PIRT Phenomena identification and ranking table \\ RES Office of Nuclear Regulatory Research \\ RHR Residual Heat Removal \\ SEA Science \& Engineering Associates, Inc. \\ UMCP University of Maryland, College Park
}




\section{FINAL REPORT \\ BWR Drywell Debris Transport \\ Phenomena Identification and Ranking Tables (PIRT)}

\section{Introduction}

\subsection{Background}

The NRC has issued a Regulatory Bulletin and accompanying Regulatory Guide (1.82, Rev. 2) ${ }^{[1]}$ which requires licensees of BWRs to develop a specific plan of action (including hardware backfits, if necessary) to preclude the possibility of early ECCS strainer blockage following a postulated LOCA. The postulated mechanism for strainer blockage is destruction of piping insulation in the vicinity of the break and subsequent transport of fragmented insulation to the wetwell. In the absence of experimental data and analytical results, demonstrating significant retention of debris in the drywell, the Regulatory Guide recommends that licensees assume $100 \%$ of debris, generated as a consequence of the LOCA, is transported from the drywell to the suppression pool. The current recommendation to use a drywell debris transport fraction of 1.0 can pose significant design impacts for some licensees.

A review of incidents that have occurred to date indicate two general categories of ECCS strainer blockage mechanisms. One (an incident in the Barsebäck plant in Sweden involving the spurious opening of a safety valve) involves debris generation in the drywell due to blast effects of high-velocity coolant discharge from the primary coolant system onto piping insulation. Similar effects are expected if a pipe running through the drywell should rupture. Transport of fibrous debris to, and collected on, ECCS strainers reduces NPSH and degrades pump performance. The second category are US incidents in which degraded RHR pump performance was observed as a consequence of pre-existing debris and sludge in the suppression pool collecting on ECCS strainers. This category has already been addressed through a separate NRC bulletin which requested periodic cleaning of BWR suppression pools.

Characterization of the debris and amount generated as a consequence of a LOCA in a BWR drywell was addressed through an experimental program supported by the BWROG.

Information from the $\mathrm{NRC}$ research ${ }^{[2]}$ (including those informally documented efforts given in Appendix C), and to a limited extent from the BWROG work, constitutes the baseline for the PIRT project described herein. 


\subsection{Objectives}

\subsubsection{USNRC BWR Debris Transport Research}

The primary objective of the NRC research program was to identify analytical methods and experimental evidence, and thereby develop a rational framework for evaluation of licensee submittals related to mitigation of strainer blockages.

\subsubsection{PIRT Project}

The primary objectives ${ }^{[3]}$ of the project for the PIRT panel were to:

1) Use the PIRT process to identify phenomena and to rank their importance as related to transport of LOCA-generated debris within US BWR drywells,

2) Use the PIRT tables to advise the NRC staff in the analysis of BWR drywell debris transport, from the perspectives of phenomena modeling and identification of present computer codes best suited for such analyses. This initial objective was subsequently expanded to include experimental aspects associated with the overall NRC research objective in Section 1.2.1 above,

3) Advise the NRC staff regarding potential methods to characterize the estimated uncertainties in code predictions and the application of calculations to predict actual plant behavior, and

4) Advise the NRC staff regarding the panel's views about the success expectancy for the experimental and analytical approaches presented to the panel.

These objectives were achieved through a four-phase approach. The first phase was focused toward timely development of initial PIRTs to guide the on-going experimental and analytical methodology development $[3,4]$. The second phase consisted of panel review and evaluation of the planned experimental program [5]. The third phase consisted of review of the preliminary experimental program results by one panel member, and reporting of his evaluation to the other panel members and the NRC[6]. The fourth and final phase, reported here, consisted of full panel review and evaluation of the final research results. The primary objective of the final phase was to update the initial PIRTs based on the new experimental and analytical evidence. A secondary objective was to provide the panel's observations and insights for the total research program.

\subsection{Report Structure}

The primary topic of interest, the PIRTs, are provided in Tables $1-2$ in Section 2. The highly ranked phenomena, extracted from these tables, are also summarized in the Executive Summary. The base conditions for which the PIRTs were developed are also provided in Section 2, in subsections preceding the tables. Phenomena descriptions and ranking 
rationales (as referenced in Tables 1 - 2) are provided, respectively in Appendices A and B. Details of the PIRT panel insights regarding the PIRTs, the debris transport related research, and other aspects of the strainer blockage issue are given in Section 3. These results are also summarized in general order of importance in the Executive Summary. Documents more directly related to the PIRT development are referenced throughout the report and identified in Section 4. Other sources of information that completed the general information base available to the panel, or developed in association with panel meetings, are summarized in Appendix C.

\section{BWR Drywell Debris Transport PIRTs}

\subsection{PIRT Process Overview}

The information obtained through the application of the PIRT process $[7,8,9]$ identifies the requirements which will be imposed on research supporting experiments and/or analytical tools used to simulate accident scenarios. In addition, those requirements are prioritized with respect to their contributions to the reactor phenomenological response to the accident scenario. Because it is not cost effective, nor required, to assess and examine all the parameters and models in a best-estimate code (or supporting experiment) in a uniform fashion, the methodology focuses on those processes and phenomena which dominate the transient behavior, although all plausible effects are considered. This screening of plausible phenomena, to determine those which dominate the plant response, ensures a sufficient and efficient analysis. PIRTs are not computer code-specific, that is, PIRTs are applicable to the scenario and plant design regardless of which code may be chosen to perform the subsequent safety analysis. This also adds to the efficiency and generality of the process.

A typical application of the PIRT process is conceptually illustrated in Figure 1 and described as follows. The PIRT process focuses on phenomena/processes that are important to the particular scenario, or class of transients, in the specified NPP (i.e., those that drive events). Plausible physical phenomena and processes, and their associated system components are identified. From a modeling perspective, phenomena/processes important to a plant response to an accident scenario can be grouped in two separate categories:

1) Higher level system interactions (integral) between components/subsystems , and 2) Those local (within) to a component/subsystem. The identification of plausible phenomena is focused toward component organization, but experience has indicated it can be most helpful to relate the phenomena to higher level integral system processes. Often time can be saved when it can be demonstrated a higher level integral system process is of 


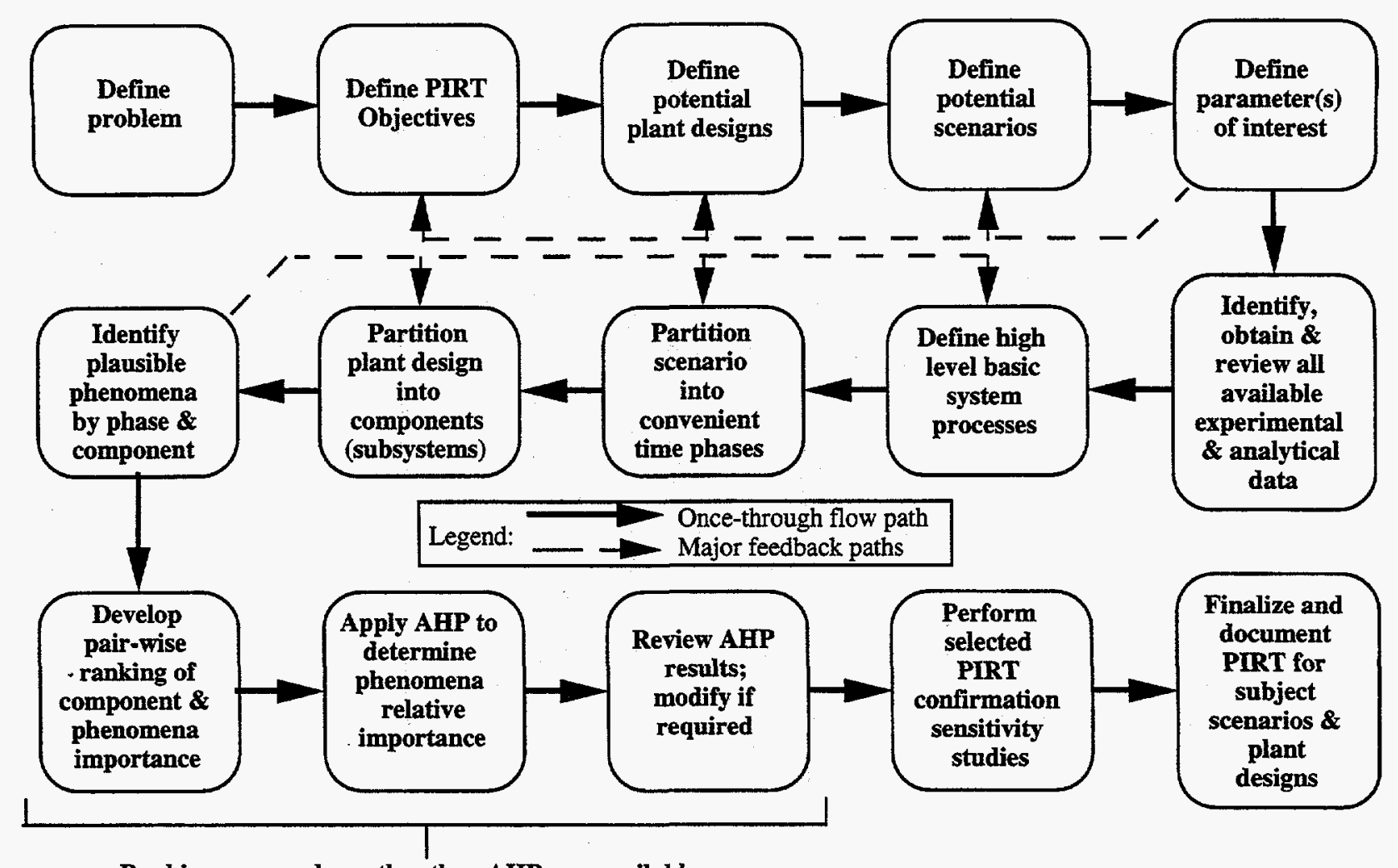

Ranking approaches, other than AHP, are available

Figure 1. Illustration of typical PIRT process.

low importance during a specific time phase. A subsequent and equally important step is the partitioning of the plant into components/subsystems. This latter step is a significant aid in organizing and ranking phenomena/processes. The phenomena/processes are then ranked with respect to their influence on the primary evaluation criteria, to establish PIRTs. Primary evaluation criteria (or criterion) are normally based on regulatory safety requirements such as those related to restrictions in fuel rods (peak clad temperature, hydrogen generation, etc.) and/or containment operation (peak pressure, ECCS performance, etc.). The rank of a phenomenon or process is a measure of its relative influence on the primary criteria (criterion). The identification and ranking are justified and documented.

The relative importance of phenomena are time dependent as an accident progresses. Thus, it is convenient to partition accident scenarios into time phases in which the dominant phenomena/processes remain essentially constant; each phase is separately investigated. The processes and phenomena associated with each component are examined as are the interrelations between the components. Cause and effect are differentiated. The processes and 
phenomena and their respective importance (rank) are judged by examination of experimental data, code simulations related to the plant and scenario, and the collective expertise and experience of the evaluation team. Independent techniques to accomplish the ranking include expert opinion, subjective decision making methods (such as the Analytical Hierarchy Process), and selected calculations. The final product of application of the PIRT process is a set of tables (PIRTs) documenting the ranks (relative importance) of phenomena and processes, by transient phase and by system component. Supplemental products include descriptions of the ranking scales, phenomena and processes definitions, evaluation criteria, and the technical rationales for each rank. In the context of the PIRT process application to drywell debris transport, the primary elements of interest are described in Sections 2.2 through 2.8. The PIRTs resulting from this specific application are documented in Section 2.9 .

\subsection{Primary Parameter of Interest}

This is the criterion that was defined and used to judge the relative importance of the phenomena/processes important to drywell debris transport. For the present PIRT endeavor, it was obvious that this parameter must be the fraction of debris mass generated within the "break region" that is transported to the wetwell vent entrance.

\subsection{Plant Design(s) Considered}

For US BWRs there are three different containment types: Mark I, Mark II and Mark III. There are a total of 37 BWR plants of which 23 have a Mark I design. It was determined that the best approach for the initial PIRT exercise was to focus first on a Mark I design because of its unique features, and then highlight differences expected to impact the other two containment designs. In summary, the approach was to develop a "generic" PIRT that is common to all three designs, but containing "exception" statements that are design specific.

\subsection{Accident Scenario(s) Considered}

Considerable effort has been given to specifying volumetric debris generation depending on various scenarios (LBLOCA, MBLOCA, steam and recirculation line break, etc.) in

NUREG/CR-6224[2]. This study further included the failure probability of numerous weld locations, various elevations, and numerous systems piping. These results concluded that this "spectrum of breaks" can lead to a large variation in volume of debris generated; namely varying from 2 to over $112 \mathrm{ft}^{3}$ of debris. Thus, the specific accident scenario considered may have some effect on the relative importance of some phenomena. To accommodate this variable within the time constraints available to complete the PIRT, the panel agreed to consider the following scenario as the primary basis for ranking phenomena: 
- Large LOCA: The objective was to base the PIRT on a bounding accident scenario (in terms of debris generation). Primary consideration was given to a steam line break, but major differences in recirculation line breaks were also recognized to account for break effluent fluid conditions.

- Full-power operation at the time of break initiation.

Again the initial approach was to develop a "generic" PIRT with respect to the different scenario conditions, but containing "exception" statements that are scenario dependent.

\subsection{Partitioning of Drywell into Components}

The panel was fortunate that prior work ${ }^{[2]}$ provided a consistent framework for partitioning the drywell into the four components pictorially illustrated in Figure 2 and described below:

- Open area: The free flow area, excluding the potential pool in the bottom of the drywell and the debris-generating zone-of-influence in the vicinity of the break.

- Structures: All solid boundaries and barriers to the flow stream, including drywell walls, pipes, cabinets, walls, grates, etc.

- Floor: That area where a potential, essentially liquid, pool may form in the lower drywell elevations.

- Vent entrance: The inlet area of the vent where significant interactions with the open area and/or floor components may take place.

Boundary conditions - Based on discussions related to the opinion that break flow was adequately characterized by the proposed methodology, and that the development of debris generation models was already well focused, it was determined these sources were best characterized as boundary conditions to the PIRT work. Therefore, there was no need to define components for these regions. That is, the PIRT process did not give consideration to primary coolant break flow, determination of a representative debris "size distribution", or other characteristics of the debris source. Debris characterization was an assumed input boundary condition. However, the influence of break flow and debris characterization on the PIRT components (i.e., interactions) was considered ${ }^{1}$. Similarly, existing information related to suppression pool behavior, constituted the vent exit boundary conditions for the PIRT development.

1 It should be noted that the panel did not necessarily agree that debris generation and characterization is a closed issue from the perspective of the overall research. However, in the absence of a definitive characterization of the debris source for particular accident scenarios, it was agreed that the PIRT development could better proceed by considering these elements as boundary conditions. 


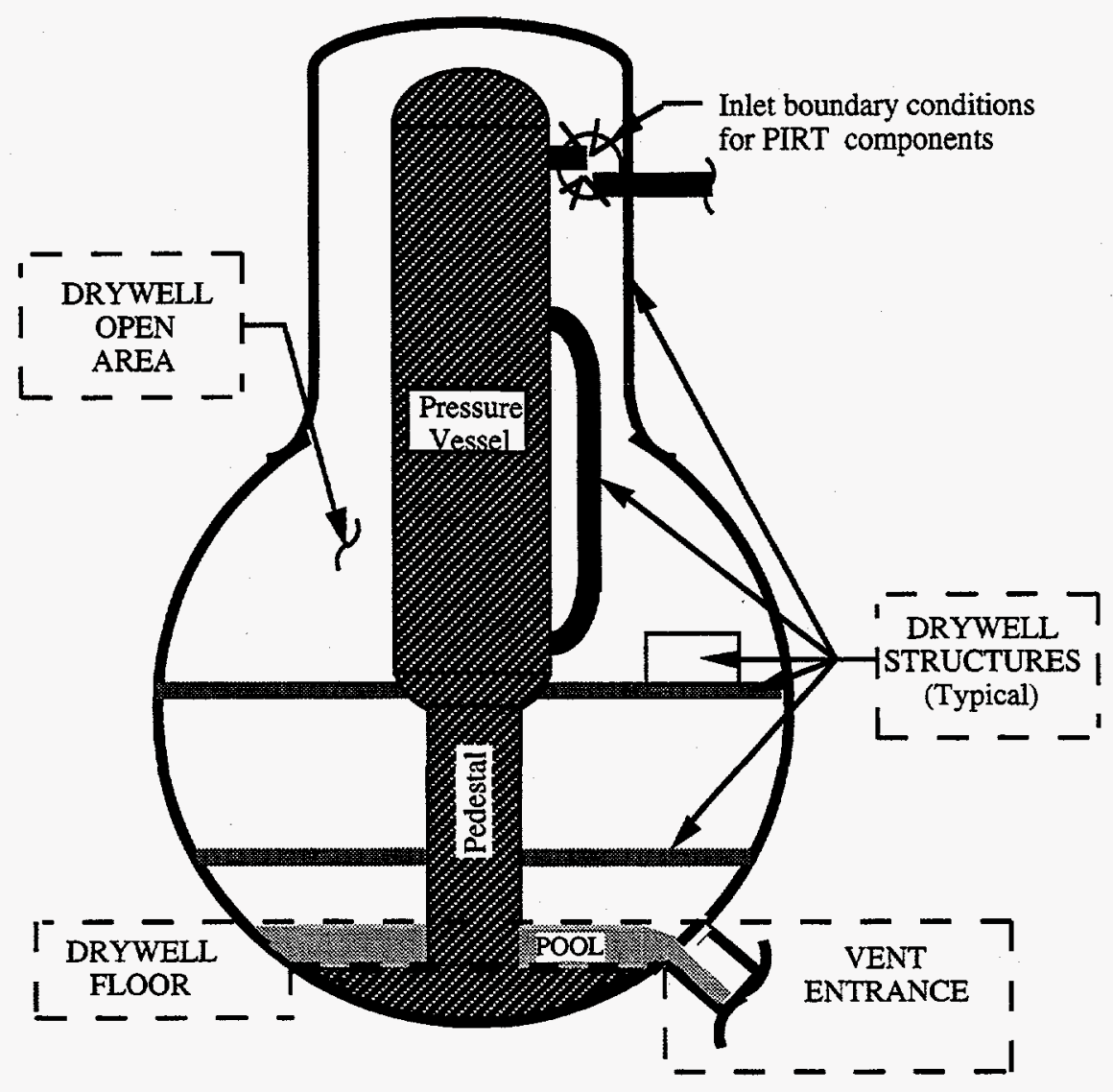

Figure 2. Component partitioning of drywell.

\subsection{Partitioning of Scenario into Time Phases}

Again prior work ${ }^{[2]}$ provided a clear resolution to this objective:

- Blowdown: From break initiation through that point where the initial, dynamic, high energy nature of the break flow has decayed to essentially constant conditions $(\approx 0$ to $100 \mathrm{~s}$ for LBLOCA). The specific time at which this phase terminates increases with decreasing break size.

- Post-blowdown: End of blowdown to that point in time when debris transport has become essentially insignificant $(\approx 30 \mathrm{~min}$ for LBLOCA). The boundary between blowdown and this phase included the specification that debris washdown by containment sprays, if present, was contained in the post-blowdown phase.

\subsection{System Level Processes}

As a first step in the PIRT process, phenomena believed to have some significance to the plant behavior were identified by the previously defined component and time phase partitioning. Early in the process it was determined that major system level interactions were 
important to identification of the plausible phenomena, and were even more important in the subsequent ranking effort. Therefore, the following five high level system processes were adopted to aid in the effort:

(1) Gas/vapor transport - Flow of noncondensibles and steam through free stream paths and around structures.

(2) Suspended water transport - Flow of liquid through free stream paths and around structures

(3) Water depletion/accumulation/surface transport - Capture, storage, and flow of liquid on the surface of drywell internal structures.

(4) Debris transport - Flow of debris through free stream paths and around structures, including transport via gas/vapor, liquid films, pool surfaces and within pools.

(5) Debris depletion - Capture and storage of debris by structures and liquid pools, including growth or fragmentation of the debris.

Features of these processes are pictorially illustrated in Figures A1-A9 in Appendix A. It may be noted that these processes were used in their broadest sense solely as an aid in organizing the phenomena into tractable groups for further consideration in the ranking of relative importance. In this sense, relating a particular phenomenon to a system level process helps to define the context in which the importance of the phenomenon is judged.

\subsection{Description of Phenomena Ranking Scale}

It was agreed that the use of the labor intensive AHP ranking methodology was not possible within the time constraints of the PIRT effort. Accordingly, it was decided that the low, medium, and high rank scheme should be adopted, where, from prior PIRT applications the following two general interpretations serve as guidelines:

1) Code development and assessment:

- Low = Phenomena has small effect on the primary parameter of interest.

Phenomena should be represented in the code, but almost any model will be sufficient,

- Medium $=$ Phenomena has moderate influence on the primary parameter of interest. Phenomena should be well modeled; accuracy maybe somewhat compromised,

- High $=$ Phenomena has dominant impact on the primary parameter of interest. Phenomena should be explicitly and accurately modeled.

2) And for code uncertainty quantification:

- Low $=$ Combined uncertainty of phenomena maybe determined in a bounding fashion, or may be eliminated when justified, 
- Medium $=$ Phenomena should be evaluated to determine if uncertainty should be treated individually as are high ranks, or in a combined manner as are low ranks,

- High $=$ Phenomena uncertainty should be individually determined and then combined statistically with other uncertainty sources (root mean square, Monte Carlo sampling, etc.).

During the actual ranking the panel found it helpful to differentiate between the lowest of the low, and highest of the high ranks. Therefore, a numerical ranking scheme of 1 to 5 was adopted with the following meaning:

$1=\underline{\text { Lowest importance }}$

4 = High importance

$2=$ Low importance $5=\underline{\text { Highest importance }}$

$3=$ Moderate importance

Because these numerical ranks better reflect the panel's ranking conclusions they have been maintained in Tables 1 and 2.

\subsection{PIRTs}

\subsubsection{Blowdown}

The PIRT for this time phase is provided in Table 1. The structure of the table is:

- Column 1 - Component in which phenomenon occurs. The components are described in Section 2.5 and Figure 2.

- Column 2 - General phenomenon type.

- Column 3 - Higher level system process with which the phenomenon is associated. These processes are described in Section 2.7.

- Column 4 - Phenomena being ranked.

- Column 5 - Cross reference number for phenomenon description given in Table A1 in Appendix A. Additional pictorial descriptions are provided in Figures A1-A6 as cross referenced in Table A1.

- Column 6 - Phenomenon relative importance rank. The ranking scheme is described at the end of Section 2.8 .

- Column 7 - Cross reference number for ranking rationale given in Table B1 in Appendix B. 


\subsubsection{Post-Blowdown}

The PIRT for this time phase is provided in Table 2. The structure of this table is similar to Table 1, except the phenomena descriptions are provided in Table A2 and Figures A7-A9 in Appendix A, and the ranking rationales are given in Table B2 in Appendix B.

\subsubsection{Ranking Summary}

The high importance phenomena from Tables 1 and 2 have also been summarized in the table in the Executive Summary at the beginning of this report, including indication of the highest of the highly ranked phenomena. 
Table 1. BWR debris transport blowdown phase PIRT

(1 of 2)

\begin{tabular}{|c|c|c|c|c|c|c|}
\hline Component & $\begin{array}{c}\text { Phenomenon } \\
\text { type }\end{array}$ & System level process & Phenomenon & $\begin{array}{l}\text { Description } \\
\text { (1) }\end{array}$ & $\begin{array}{c}\text { Rank } \\
\text { (2) }\end{array}$ & $\begin{array}{l}\text { Ranking } \\
\text { rational }^{(3)}\end{array}$ \\
\hline \multirow{17}{*}{$\begin{array}{l}\text { Drywell } \\
\text { open } \\
\text { areas }\end{array}$} & \multirow{9}{*}{$\begin{array}{l}\text { Thermal } \\
\text { hydraulic } \\
\text { related }\end{array}$} & \multirow[t]{4}{*}{ Gas/vapor transport } & Pressure driven flows (bulk flows) & $\overline{1}$ & 5 & 1 \\
\hline & & & Mixing (noncondensibles) & 2 & 1 & 2 \\
\hline & & & Localized flow field & 3 & 5 & 3 \\
\hline & & & Turbulence & 4 & 2 & 4 \\
\hline & & \multirow{3}{*}{$\begin{array}{l}\text { Suspended water transport (incl. gravitational } \\
\text { settling) }\end{array}$} & Flashing of break liquid effluent & 5 & $1(5)^{(4)}$ & 5 \\
\hline & & & Droplet interactions & 6 & 1 & 6 \\
\hline & & & Condensation (droplet formation) & 7 & 1 & 7 \\
\hline & & \multirow{2}{*}{$\begin{array}{l}\text { Water surface transport depletion/accumulation/ } \\
\text { (implied surface orientation) }\end{array}$} & Condensation (structural) & 8 & 1 & 8 \\
\hline & & & Film Dynamics & 9 & 1 & 8 \\
\hline & \multirow{8}{*}{$\begin{array}{l}\text { Debris } \\
\text { related }\end{array}$} & \multirow[t]{4}{*}{ Debris transport } & Advection/slip & 10 & 5 & 9 \\
\hline & & & Agglomeration & 11 & 2 & 10 \\
\hline & & & Debris/Flow field coupling & 12 & 1 & 11 \\
\hline & & & Debris fragmentation & 13 & 3 & 12 \\
\hline & & \multirow[t]{4}{*}{ Debris depletion } & Gravitational settling & 14 & 3 & 13 \\
\hline & & & Condensation on particles & 15 & 1 & 14 \\
\hline & & & Stephan flow (diffuseophoresis) & 16 & 1 & 15 \\
\hline & & & Thermophoresis & 17 & 1 & 15 \\
\hline \multirow{13}{*}{$\begin{array}{l}\text { Drywell } \\
\text { structures }\end{array}$} & \multirow{6}{*}{$\begin{array}{l}\text { Thermal } \\
\text { hydraulic } \\
\text { related }\end{array}$} & Gas/vapor transport & Heat transfer & 18 & 1 & 16 \\
\hline & & \multirow{5}{*}{$\begin{array}{l}\text { Water surface transport depletion/accumulation/ } \\
\text { (implied surface orientation) }\end{array}$} & Porosity & 19 & 5 & 3 \\
\hline & & & Film shear & 20 & 1 & 17 \\
\hline & & & Surface wetting (condensation, impact) & 21 & 5 & 18 \\
\hline & & & Film draining under gravity & 22 & 1 & 19 \\
\hline & & & Recirculation (streaming) deluge & 23 & 5 & 20 \\
\hline & \multirow{7}{*}{$\begin{array}{l}\text { Debris } \\
\text { related }\end{array}$} & \multirow[t]{5}{*}{ Debris transport } & Resuspension & 24 & 2 & 21 \\
\hline & & & Agglomeration & 25 & 2 & 22 \\
\hline & & & $\begin{array}{l}\text { Recirculation deluge (streaming) } \\
\text { related transport }\end{array}$ & 26 & $1(5)^{(4)}$ & 20 \\
\hline & & & Film related transport & 27 & 1 & 19 \\
\hline & & & Runoff/reentrainment & 28 & 1 & 23 \\
\hline & & \multirow[t]{2}{*}{ Debris depletion } & Impaction & 29 & 5 & 24 \\
\hline & & & Adhesion & 30 & 5 & 24 \\
\hline
\end{tabular}


Table 1. BWR debris transport blowdown phase PIRT ( 2 of 2)

\begin{tabular}{|c|c|c|c|c|c|c|}
\hline Component & $\begin{array}{c}\text { Phenomenon } \\
\text { type }\end{array}$ & System level process & Phenomenon & Description & Rank & $\begin{array}{l}\text { Ranking } \\
\text { rational }\end{array}$ \\
\hline \multirow{11}{*}{$\begin{array}{l}\text { Drywell } \\
\text { floor }\end{array}$} & \multirow{5}{*}{$\begin{array}{l}\text { Thermal } \\
\text { hydraulic } \\
\text { related }\end{array}$} & \multirow{5}{*}{$\begin{array}{l}\text { Water surface transport depletion/accumulation/ } \\
\text { (implied surface orientation) }\end{array}$} & Pool formation & 31 & $1(5)$ & 25 \\
\hline & & & Pool overflow (timing issue this phase) & 32 & $1(5)$ & 25 \\
\hline & & & Heat transfer to structure & 33 & 2 & 26 \\
\hline & & & Surface wetting (before pool formation) & 34 & 2 & 25,27 \\
\hline & & & Pool flow dynamics & 35 & $1(4)$ & 25 \\
\hline & \multirow{6}{*}{$\begin{array}{l}\text { Debris } \\
\text { related }\end{array}$} & \multirow[t]{2}{*}{ Debris transport } & Resuspension & 36 & 2 & 28 \\
\hline & & & Pool transport (to/through vent) & 37 & $1(5)$ & 25 \\
\hline & & \multirow[t]{4}{*}{ Debris depletion } & Agglomeration in pool & 38 & $1(3)$ & 25 \\
\hline & & & Adhesion & 39 & 2 & 25,27 \\
\hline & & & Settling & 40 & $1(4)$ & 25 \\
\hline & & & Impaction & 41 & 2 & 25,27 \\
\hline \multirow{5}{*}{$\begin{array}{l}\text { Vent } \\
\text { entrance }\end{array}$} & \multirow{3}{*}{$\begin{array}{l}\text { Thermal } \\
\text { hydraulic } \\
\text { related }\end{array}$} & \multirow[t]{2}{*}{ Gas/vapor transport } & Pressure driven flow (bulk) (vapor/gas) & 42 & 1 & 29 \\
\hline & & & Localized vapor flow field & 43 & 1 & 29 \\
\hline & & $\begin{array}{l}\text { Water surface transport depletion/accumulation/ } \\
\text { (implied surface orientation) }\end{array}$ & Localized liquid flow field & 44 & $\overline{1}$ & 29 \\
\hline & \multirow{2}{*}{$\begin{array}{l}\text { Debris } \\
\text { related }\end{array}$} & Debris transport & Advected mass & 45 & 1 & 29 \\
\hline & & Debris depletion & Entrainment & 46 & 3 & 29 \\
\hline
\end{tabular}

\section{Notes}

(1): See Appendix A for phenomena descriptions.

(2): 1 = Lowest importance to debris transport through the drywell to the wetwell; $3=$ Moderate importance; $5=$ Highest importance; 2 and 4 allow further refinement, where 2 is considered low importance and 4 is considered high importance.

(3): See Appendix $B$ for ranking rationales.

(4): First entry (without brackets) applies to main steam line break; the value in () applies to the recirculation line break; Typical of all entries so indicated. 
Table 2. BWR debris transport post-blowdown phase PIRT

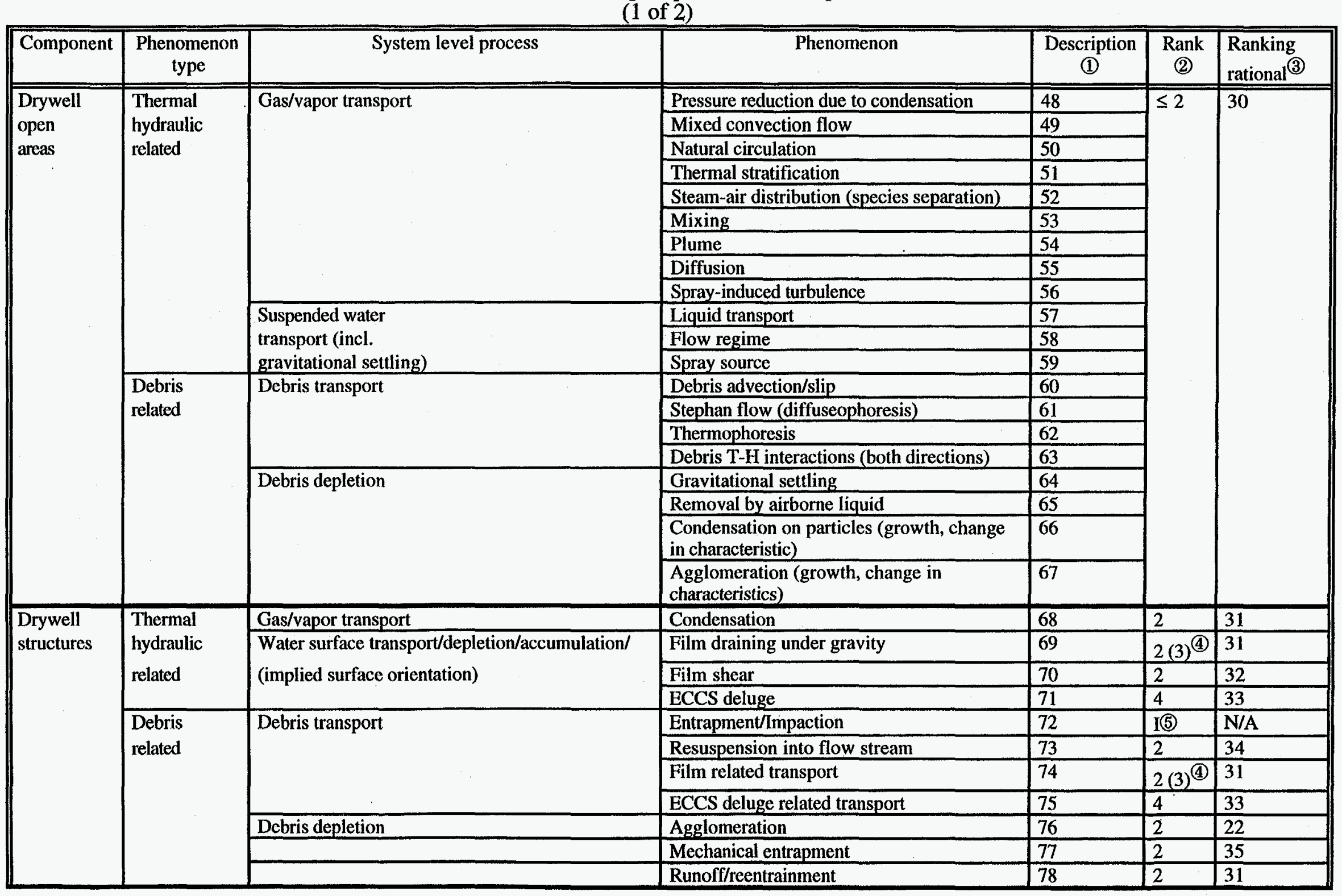


Table 2. BWR debris transport post-blowdown phase PIRT (2 of 2)

\begin{tabular}{|c|c|c|c|c|c|c|}
\hline Component & \begin{tabular}{|c|}
$\begin{array}{c}\text { Phenomenon } \\
\text { type }\end{array}$ \\
\end{tabular} & System level process & Phenomenon & & Rank & $\begin{array}{l}\text { Ranking } \\
\text { rational }\end{array}$ \\
\hline \multirow{11}{*}{$\begin{array}{l}\text { Drywell } \\
\text { floor }\end{array}$} & \multirow{5}{*}{$\begin{array}{l}\text { Thermal } \\
\text { hydraulic } \\
\text { related }\end{array}$} & Gas/vapor transport & Heat transfer to structure & 79 & 2 & 36 \\
\hline & & \multirow{4}{*}{$\begin{array}{l}\text { Water depletion/accumulation/surface/transport } \\
\text { (implied surface orientation) }\end{array}$} & Pool overflow & 80 & $4^{(6)}$ & 37 \\
\hline & & & Asymmetric effects & 81 & 1 & 38 \\
\hline & & & Pool formation & 82 & $4^{(6)}$ & 39 \\
\hline & & & Pool flow dynamics & 83 & $3(5)^{(4)}$ & 40 \\
\hline & \multirow{6}{*}{$\begin{array}{l}\text { Debris } \\
\text { related }\end{array}$} & Debris transport & Pool transport (to/toward vent) & 84 & $3(5)^{(4)}$ & 40 \\
\hline & & Debris depletion & Settling & 85 & $4^{(6)}$ & 41 \\
\hline & & & Impaction & 86 & 1 & N/A \\
\hline & & & Resuspension into drywell open area & 87 & I & N/A \\
\hline & & & Agglomeration & 88 & $1(3)^{(4)}$ & 22 \\
\hline & & & Debris fragmentation & 89 & $1(2)^{(4)}$ & 42 \\
\hline \multirow{6}{*}{$\begin{array}{l}\text { Vent } \\
\text { entrance }\end{array}$} & \multirow{4}{*}{$\begin{array}{l}\text { Thermal } \\
\text { hydraulic } \\
\text { related }\end{array}$} & \multirow[t]{2}{*}{ Gas/vapor transport } & Press-driven flow (bulk) & 90 & 1 & 43 \\
\hline & & & Localized vapor flow field & 91 & 1 & 43 \\
\hline & & \multirow{2}{*}{$\begin{array}{l}\text { Suspended water transport (incl. gravitational } \\
\text { settling) } \\
\text { Water depletion/accumulation/surface transport } \\
\text { (implied surface orientation) }\end{array}$} & Advected liquid mass & 92 & 1 & 44 \\
\hline & & & Localized liquid flow field & 93 & $1(3)^{(4)}$ & 39 \\
\hline & \multirow[t]{2}{*}{ Debris related } & Debris transport & Advected mass & 94 & $1(3)^{(4)}$ & 45 \\
\hline & & Debris depletion & De-entrainment and/or re- entrainment & 95 & 2 & 43 \\
\hline
\end{tabular}

Notes

(1): See Appendix A for phenomena descriptions.

(2): $1=$ Lowest importance to debris transport through the drywell to the wetwell; $3=$ Moderate importance; $5=$ Highest importance; 2 and 4 allow further refinement, where 2 is considered low importance and 4 is considered high importance.

(3): See Appendix B for ranking rationales.

(4): First entry (without brackets) applies to main steam line break in which it is most unlikely there will be overflow of the drywell pool. Ranking in () applies to the recirculation line break, particularly when the drywell overflows.

(5): Indicated phenomena has insignificant effect on debris transport through the drywell to the wetwell (typical of all entries so indicated and listed solely to show phenomena was considered, but rejected as having any significance).

(6): Applies only to non-throttled ECCS conditions; otherwise the rank is low $(<3)$. 


\section{Panel Insights Regarding BWR Debris Transport}

The information provided in Table 3 was developed by the NRC to help guide the panel deliberations. The PIRT results provided in Section 2 and the experimental and analytical research related insights given below were strongly influenced by the needs and objectives stated in Table 3 .

Table 3. Goals and associated success criteria for NRC-NRR's development and application of an analysis framework for evaluating debris transport.

\begin{tabular}{|c|c|c|c|}
\hline Goal & Approach & Product & Success Criteria \\
\hline $\begin{array}{l}\text { Identify \& rank } \\
\text { important } \\
\text { phenomena }\end{array}$ & PIRT & PIRT report & $\begin{array}{l}\text { a) Consensus ranking of most } \\
\text { important phenomena } \\
\text { b) Whether identified phenomena } \\
\text { can be incorporated into } \\
\text { calculational tools identified }\end{array}$ \\
\hline $\begin{array}{l}\text { Develop calculational } \\
\text { methodology }\end{array}$ & $\begin{array}{l}\text { Evaluate applicable } \\
\text { calculational tools \& transport } \\
\text { models (i.e., MELCOR/CFD), } \\
\text { test against available } \\
\text { information or related use. Use } \\
\text { PIRT panel experts \& other } \\
\text { analysts if needed }\end{array}$ & $\begin{array}{l}\text { Calculational } \\
\text { methods \& models to } \\
\text { estimate fraction of } \\
\text { debris transported to } \\
\text { wetwell }\end{array}$ & $\begin{array}{l}\text { Calculational methodology which } \\
\text { accounts for important } \\
\text { phenomena \& judged by experts } \\
\text { to have a basis for acceptance \& } \\
\text { application }\end{array}$ \\
\hline $\begin{array}{l}\text { Apply calculational } \\
\text { methodology }\end{array}$ & $\begin{array}{l}\text { Perform MARK I, II \& III } \\
\text { reference plant calculations }\end{array}$ & $\begin{array}{l}\text { Containment specific } \\
\text { calculations which } \\
\text { estimate fraction of } \\
\text { debris which might } \\
\text { be transported to the } \\
\text { wetwell }\end{array}$ & $\begin{array}{l}\text { Provide insights into important } \\
\text { plant modeling requirements \& } \\
\text { calculational method(s) influences }\end{array}$ \\
\hline $\begin{array}{l}\text { Estimate } \\
\text { calculational } \\
\text { sensitivities \& } \\
\text { uncertainties }\end{array}$ & $\begin{array}{l}\text { Perform sensitivity \& } \\
\text { uncertainty analyses for } \\
\text { reference plant conditions }\end{array}$ & $\begin{array}{l}\text { Parametric trends \& } \\
\text { uncertainty estimates } \\
\text { for debris transport } \\
\text { fractions }\end{array}$ & $\begin{array}{l}\text { a) Confirm ranking of } \\
\text { controlling phenomena \& use } \\
\text { of selected codes/models } \\
\text { b) Ability to perform evaluations } \\
\text { without need to commit } \\
\text { extensive resources }\end{array}$ \\
\hline $\begin{array}{l}\text { Respond to NRR } \\
\text { USER needs to } \\
\text { understand key } \\
\text { phenomena \& their } \\
\text { significance in } \\
\text { review of licensee } \\
\text { submittals } \\
\end{array}$ & $\begin{array}{l}\text { Use insights gained from above } \\
\text { to judge licensee estimates of } \\
\text { debris transport in the drywell }\end{array}$ & $\begin{array}{l}\text { Technical findings } \\
\text { report with condensed } \\
\text { guidelines }\end{array}$ & $\begin{array}{l}\text { Clarity \& ease of applying } \\
\text { insights from methodology \& } \\
\text { sample plant calculations }\end{array}$ \\
\hline
\end{tabular}

(1) Uncertainty in this context relates to statements of realistic bounds on the parameters of interest, rather than to statistically based quantification and characterization of uncertainty often associated with the term "uncertainty analysis".

\subsection{PIRT Related Insights}

The insights given below are primarily in the context of lessons learned at the conclusion of the PIRT effort.

1) The generic PIRT process was readily adapted to the needs of the program and proved to be an effective method to organize a highly complex problem into tractable subparts. 
Consequently, the results were used in planning and conducting the continuing research. Two panel recommendations and one warning developed from the PIRT efforts were found to be of particular utility:

- Recommendation to perform end-to-end calculations,

- Recommendation to develop a methodology that an engineer not familiar with the issue could understand, and

- Warning that the resources needed to successfully validate the computer codes, initially considered for a methodology strongly based on analytical modeling, was considered beyond those available to the program.

2) Comparison of the final PIRTs with the initial PIRTs $[3,4]$ tends to further validate the effectiveness of using independent teams, having collective broad based knowledge, early in research programs addressing new problems, as illustrated by the following:

- No new phenomena were identified

- One phenomenon rank moved from moderate to high rank, based on new evidence (i.e., surface wetting during the blowdown phase)

- In two cases the ranks of related phenomenon effects moved from low to high (i.e., ECCS deluge influence on thermal hydraulics and on debris transport during the post-blowdown phase)

- Three phenomenon ranks moved from high importance to highest importance (i.e., pool formation, pool overflow and pool transport to/through the vent during the blowdown phase)

- Although the ranks of several phenomena were increased, the most noticeable trend between the initial and final PIRTs was the decrease in phenomena importance. This validates the built-in rule in the process, that in the absence of evidence, the team is to initially rank phenomena at their highest conceivable rank until further evidence is acquired as to the more realistic rank.

\subsection{Methodology to Synthesize Research Results Into a Basis to Judge Licensee Submittals}

1) The panel believes the structure of the methodology:

- Will provide a rational technical basis for the desired licensing review 
- Is sufficiently flexible that new evidence and assumptions, related to debris size and distribution, can quickly be accommodated to provide basis for submittal evaluations not covered at the time this report was issued

2) The panel finds the methodology attractive in that it:

- Clearly delineates important phenomena in the BWR drywell

- Readily incorporates, and links, both experimental and analytical results

- Is comprehensible to engineers having less experience in the subject of interest

3) With respect to the current application of the methodology, the panel perceives the following potential weaknesses2:

- The rationale for upper bounds on the transport fraction needs to be strengthened. The consistently small differences between the central and upper bound values in the current application of the methodology need to be better demonstrated as realistic, or as unimportant. In addition, the use of 0.00 and 1.00 lower and upper bound values is considered unrealistic, particularly on the basis of engineering judgment. Given the inherent complexity of the phenomenological problem, and the diversity in BWR containment designs, it is surprising that the methodology produces such a small range of variation in transport factor for the sample case documented thus far. The panel believes this could be the result of the applied sample data, and suggests application of the methodology with a different data set to demonstrate this is not a generic, inherent characteristic of the methodology.

- The ultimate quantitative insights provided by the methodology are influenced by the assumed character of the generated debris. Useful insights as to that character have been gained through the BWROG, CEESI and ARL experiments. However, the panel believes additional independent validation of the potential character of the generated debris is desirable. Without more complete knowledge of debris size distribution the upper bound uncertainties may be too low and, thus possible nonconservative.

The panel believes it is important that the above two comments be put into perspective by recognizing both items can be accommodated to a large extent by using higher upper bound values for the parameters of interest. However, doing so leads to increased

${ }^{2}$ It should be noted the PIRT panel reviewed the subject methodology prior to completion of formal documentation in D. V. Rao et al., Drywell Debris Study: Final Report, NUREG/CR-6369, SEA, Inc. (September 1997). Details of the methodology can be found in the indicated NUREG. To the extent the panel's comments are addressed in the NUREG, those comments herein may no longer apply. 
uncertainty in the ultimate quantitative insights provided by the methodology (and imposes the burden that a valid rationale for the assumed upper bounds be provided).

- The basis for the applied flow velocities in the ARL and CEESI experiments needs to be strengthened. That is, their applicability to prototypical plant conditions needs to be more strongly demonstrated.

- The experimental data base for the behavior (including ECCS erosion) of large debris on gratings is considered incomplete. In some part this is related to the above item. The data base was constructed based on limited BWROG and ARL experimental results that indicate medium and large pieces of insulation, retained by the grating, are not significantly fragmented as blowdown of the drywell progresses. The panel suggests that further separate effect tests, at prototypical conditions, could significantly increase the confidence that the medium and large debris are mostly retained by the gratings.

- The data base for the recirculation line LOCA is considered too small relative to the importance of that transient and its consequences. That is, the largest part of the research was focused on the MSLB, while the highest estimated transport fractions were associated with the recirculation line break.

4) The PIRT panel believes that the overall BWR LOCA-debris drywell transport problem is inherently very complex. The panel is not aware of any existing analytical tool (computer code) available to handle these phenomena in a fully integrated manner. Even state-of-the-art separate effects CFD codes are lacking in some key aspects, e.g., inertial impaction of debris. Therefore, the panel considers it unlikely that a purely predictive approach to issue resolution can be successfully defended with current state-of-the-art analytical tools. From this perspective the panel concludes:

- The NRC objectives (see Table 3) for the research were well founded and appropriate

- The mid-course change in the research, to obtain more experimental data and move away from a heavy dependency on an analytical tool(s), was appropriate

- The methodology developed to synthesize the experimental data and analysis results was a suitable and scrutable approach to provide the desired insights for auditing licensee submittals 


\section{References}

[1] USNRC, Water Sources for Long-Term Recirculation Cooling Following a Loss-of-Coolant Accident, Regulatory Guide 1.82, Revision 2 (May 1996).

[2] G. Zigler et al., Parametric Study of the Potential for BWR ECCS Strainer Blockage Due to LOCA Generated Debris, NUREG/CR-6224, Science And Engineering Associates, Inc. (October 1995).

[3] Letter Report: Summary Minutes: First BWR Debris Transport PIRT Meeting, Transmitted by letter GEW-12-96 (May 20, 1996).

[4] Letter Report: Transmittal Of Initial BWR Debris Transport PIRT, Gary E. Wilson to Aleck Serkiz, transmitted by GEW-14-96 (6/27/96).

[5] Letter Report: Transmittal Of BWR Debris Transport PIRT Panel Review Of SEA Experimental Plan, Gary E. Wilson to Aleck Serkiz, transmitted by GEW-47-96 (11/15/96).

[6] Letter Report: January 28-29, 1997, Drywell Task Program Review and Planning Meeting, Brent E. Boyack to Gary E. Wilson, transmitted by TSA-10-97-158 (2/10/98).

[7] TPG (Technical Program Group), Quantifying Reactor Safety Margins: Application of CSAU to a LBLOCA, NUREG/CR-5249, EG\&G Idaho, Inc. (1989)

[8] TPG (Technical Program Group), Quantifying Reactor Safety Margins: Application of CSAU to a LBLOCA, Nuclear Engineering and Design 119 (1990):

B. E. Boyack et al., Part 1: An overview of the CSAU Evaluation Methodology, G. E. Wilson et al., Part 2: Characterization of Important Contributors to Uncertainty, W. Wulff et al., Part 3: Assessment and Ranging of Parameters, G. S. Lellouche et al.,PART 4: Uncertainty Evaluation of LBLOCA Analysis Based on TRAC-PF1/MOD1,

N. Zuber et al., Part 5: Evaluation of Scale-Up Capabilities of Best Estimate Codes, I. Catton et al., Part 6: A Physically Based Method of Estimating PWR LBLOCA PCT.

[9] R. A. Shaw, T. K. Larson and R. K. Dimenna, Development of a Phenomena Identification and Ranking Table (PIRT) for Thermal-Hydraulic Phenomena During a PWR LBLOCA, NUREG/CR-5074, EG\&G Idaho, Inc. (1988). 
Appendix A:

Phenomena Descriptions for BWR Debris Transport PIRTs 
Table A1. Phenomena descriptions for BWR debris transport blowdown phase PIRT (1 of 4) (Reference number relates to entry in Table 1 in the report main body)

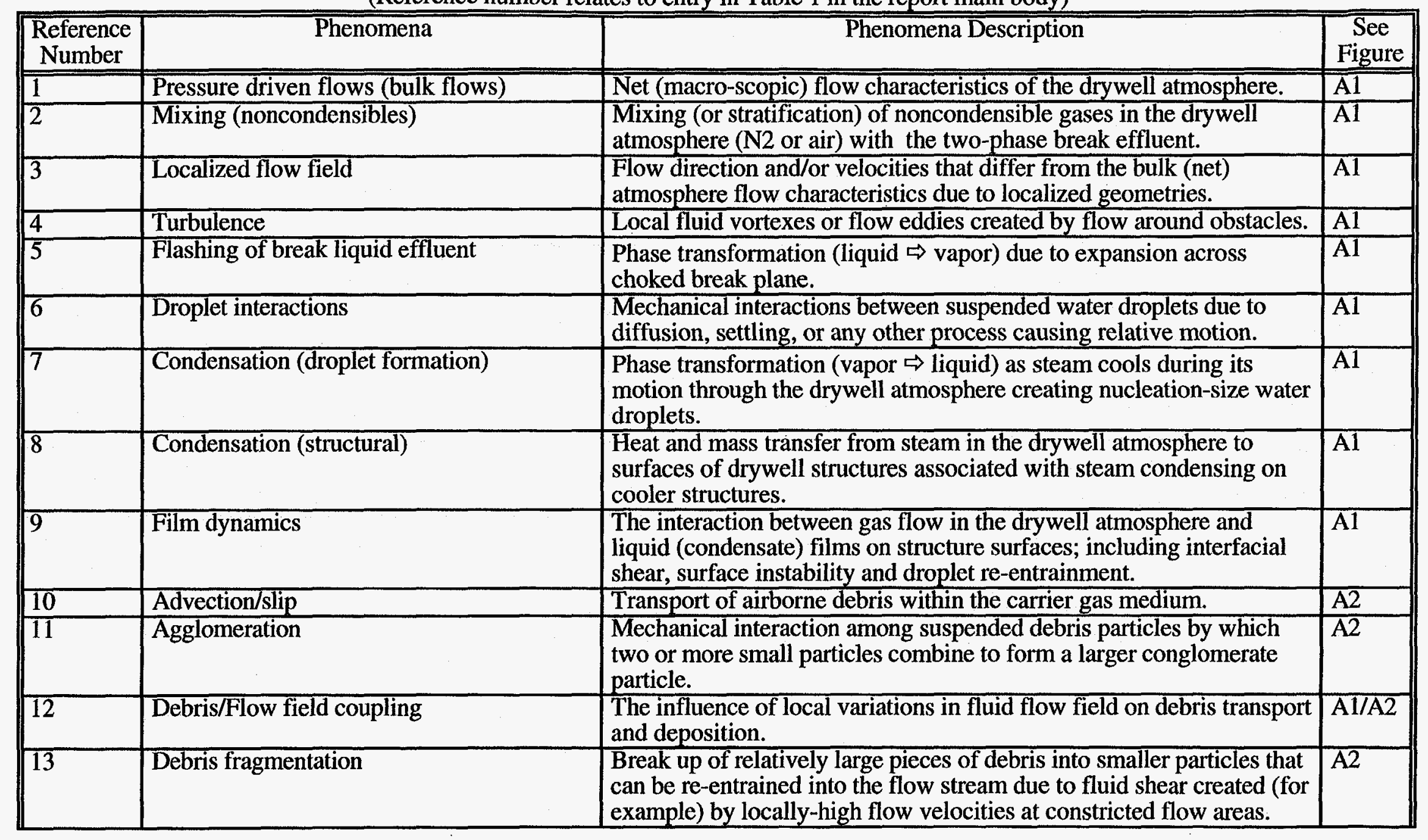


Table A1. Phenomena descriptions for BWR debris transport blowdown phase PIRT (2 of 4)

\begin{tabular}{|c|c|c|c|}
\hline $\begin{array}{l}\text { Reference } \\
\text { Number }\end{array}$ & Phenomena & Phenomena Description & $\begin{array}{c}\text { See } \\
\text { Figure }\end{array}$ \\
\hline$\overline{14}$ & Gravitational settling & $\begin{array}{l}\text { Downward relocation (sedimentation) of debris in the drywell } \\
\text { atmosphere onto structure surfaces under the force of gravity. }\end{array}$ & $\overline{\mathrm{A} 2}$ \\
\hline 15 & Condensation on particles & $\begin{array}{l}\text { Heat and mass transfer from steam in the drywell atmosphere to } \\
\text { surfaces of suspended debris particles with steam condensing onto } \\
\text { particle surface. }\end{array}$ & A2 \\
\hline 16 & Stephan flow (diffusiophoresis) & $\begin{array}{l}\text { Transport of debris particles toward deposition surfaces due to } \\
\text { concentration gradients of atmosphere contents (dominated by steam } \\
\text { concentration gradients created by condensation on drywell } \\
\text { structures). }\end{array}$ & A2 \\
\hline 17 & Thermophoresis & $\begin{array}{l}\text { Transport of debris particles toward deposition surfaces due to } \\
\text { temperature gradients within the atmosphere and between the } \\
\text { atmosphere and bounding structures. }\end{array}$ & $\overline{\mathrm{A} 2}$ \\
\hline 18 & Heat transfer & Cooling of drywell atmosphere due to heat transfer to structures. & A3 \\
\hline 19 & Porosity & $\begin{array}{l}\text { Variations in fluid flow area and flow as related to the density of the } \\
\text { structures in the drywell, and due to the "tortureosity" of the flow } \\
\text { path around those structures. }\end{array}$ & $\overline{\mathrm{A} 3}$ \\
\hline 20 & Film shear & $\begin{array}{l}\text { The interfacial interaction between gas flow in the drywell atmosphere } \\
\text { and liquid (condensate) films on structure surfaces. }\end{array}$ & A3 \\
\hline 21 & Surface wetting (condensation, impact) & $\begin{array}{l}\text { Formation of a liquid film on structure surfaces due to condensation } \\
\text { of steam from the atmosphere or impaction of water droplets onto } \\
\text { structure surfaces. }\end{array}$ & $\overline{\mathrm{A} 3}$ \\
\hline 22 & Film draining under gravity & $\begin{array}{l}\text { Downward, free-surface flow of liquid (water) films on structure } \\
\text { surfaces by gravity. }\end{array}$ & A3 \\
\hline 23 & Recirculation (streaming) deluge & $\begin{array}{l}\text { Large flow rate of liquid effluent from a low-elevation (e.g., } \\
\text { recirculation line) break in the reactor coolant system onto drywell } \\
\text { structures, or from sprays when activated. }\end{array}$ & $\overline{\mathrm{A} 3}$ \\
\hline 24 & Resuspension & $\begin{array}{l}\text { Re-entrainment of debris previously deposited on structure surfaces } \\
\text { into the atmosphere flow stream due to local fluid/structure shear } \\
\text { forces. }\end{array}$ & $\overline{\mathrm{A} 4}$ \\
\hline 25 & Agglomeration & $\begin{array}{l}\text { Mechanical interaction among debris particles on structure surfaces } \\
\text { (i.e., within a liquid film) by which two or more small particles } \\
\text { combine to form a larger conglomerate particle. }\end{array}$ & $\overline{\mathrm{A} 4}$ \\
\hline
\end{tabular}


Table A1. Phenomena descriptions for BWR debris transport blowdown phase PIRT (3 of 4)

\begin{tabular}{|c|c|c|c|}
\hline $\begin{array}{l}\text { Reference } \\
\text { Number }\end{array}$ & Phenomena & Phenomena Description & $\begin{array}{c}\text { See } \\
\text { Figure }\end{array}$ \\
\hline 26 & $\begin{array}{l}\text { Recirculation deluge (streaming) } \\
\text { related transport }\end{array}$ & $\begin{array}{l}\text { Relocation of debris from drywell structures due to interactions with } \\
\text { the deluge of liquid from recirculation pipe breaks, or sprays. }\end{array}$ & $\mathrm{A4}$ \\
\hline 27 & Film related transport & $\begin{array}{l}\text { Relocation of debris along structure surfaces due to flow of liquid } \\
\text { films under the force of gravity. }\end{array}$ & $\overline{\mathrm{A} 4}$ \\
\hline 28 & Runoff/re-entrainment & $\begin{array}{l}\text { Re-suspension of debris on structure surfaces into the flow stream as } \\
\text { liquid films drain off of structures. }\end{array}$ & $\mathrm{A} 4$ \\
\hline 29 & Impaction & $\begin{array}{l}\text { Capture of debris particles on structure surfaces due to inertial } \\
\text { impaction. }\end{array}$ & A4 \\
\hline 30 & Adhesion & $\begin{array}{l}\text { Permanent retention of debris particles on a structure surface due to } \\
\text { mechanical interactions with a rough surface or other forces. }\end{array}$ & $\overline{A 4}$ \\
\hline 31 & Pool formation & $\begin{array}{l}\text { Creation of a pool of water on the drywell floor sufficiently deep to } \\
\text { allow overflow into wetwell transfer piping due to the accumulation } \\
\text { of water from all sources higher in the drywell (e.g., film drainage, } \\
\text { droplet settling). }\end{array}$ & A5 \\
\hline 32 & Pool overflow (timing issue this phase) & $\begin{array}{l}\text { Transport of water from pool on drywell floor into wetwell vent } \\
\text { pipes. }\end{array}$ & A5 \\
\hline 33 & Heat transfer to structure & Heat transfer between water on drywell floor and bounding structures & $\bar{A} \overline{5}$ \\
\hline 34 & Surface wetting (before pool formation) & $\begin{array}{l}\text { Wetting of drywell floor due to steam condensation or settling of } \\
\text { suspended water droplets. }\end{array}$ & $\overline{A 5}$ \\
\hline 35 & Pool flow dynamics & $\begin{array}{l}\text { Multi-dimensional flow patterns and velocities within the pool of } \\
\text { water on the drywell floor; includes free-surface (vertical) velocity } \\
\text { profile and turbulent mixing (circulation) flows. }\end{array}$ & A5 \\
\hline 36 & Resuspension & $\begin{array}{l}\text { Re-entrainment of debris into the atmospheric flow stream from the } \\
\text { drywell floor due to high shear forces at the surface of the floor. }\end{array}$ & A6 \\
\hline 37 & Pool transport (to/through vent) & $\begin{array}{l}\text { Relocation of debris in the pool of water on the drywell floor toward } \\
\text { wetwell vent pipe entrances. }\end{array}$ & $\mathrm{A} 6$ \\
\hline 38 & Agglomeration in pool & $\begin{array}{l}\text { Mechanical interaction among debris particles in the pool of water on } \\
\text { the floor by which two or more small particles combine to form a } \\
\text { larger conglomerate particle. }\end{array}$ & A6 \\
\hline 39 & Adhesion & $\begin{array}{l}\text { Permanent retention of debris particles on the drywell floor due to } \\
\text { mechanical interactions with a rough surface or other forces. }\end{array}$ & $\mathrm{A} 6$ \\
\hline 40 & Settling & $\begin{array}{l}\text { Downward relocation (sedimentation) of debris within the pool of } \\
\text { water on the drywell floor under the force of gravity. }\end{array}$ & A6 \\
\hline
\end{tabular}


Table A1. Phenomena descriptions for BWR debris transport blowdown phase PIRT (4 of 4)

\begin{tabular}{|c|c|c|c|}
\hline $\begin{array}{l}\text { Reference } \\
\text { Number }\end{array}$ & Phenomena & Phenomena Description & $\begin{array}{c}\text { See } \\
\text { Figure }\end{array}$ \\
\hline 41 & Impaction & $\begin{array}{l}\text { Capture of debris on the surface of the drywell floor (or water pool) } \\
\text { due to inertial deposition. }\end{array}$ & $\mathrm{A} 6$ \\
\hline$\overline{42}$ & Pressure driven flow (bulk) (vapor/gas) & \multicolumn{2}{|l|}{ Vent entrance component phenomenon similar to Ref. No. 1, this table. } \\
\hline 43 & Localized vapor flow field & \multicolumn{2}{|l|}{ Vent entrance component phenomenon similar to Ref. No. 3 , this table. } \\
\hline 44 & Localized liquid flow field & \multicolumn{2}{|l|}{ Vent entrance component phenomenon similar to Ref. No. 3, this table. } \\
\hline 45 & Advected mass & \multicolumn{2}{|l|}{ Vent entrance component phenomenon similar to Ref. No. 10 , this table. } \\
\hline 46 & Entrainment & Capture of debris from the bulk flow stream. & $\mathrm{A} 5, \mathrm{~A} 6$ \\
\hline 47 & \multicolumn{3}{|l|}{ Deleted in final PIRT } \\
\hline
\end{tabular}




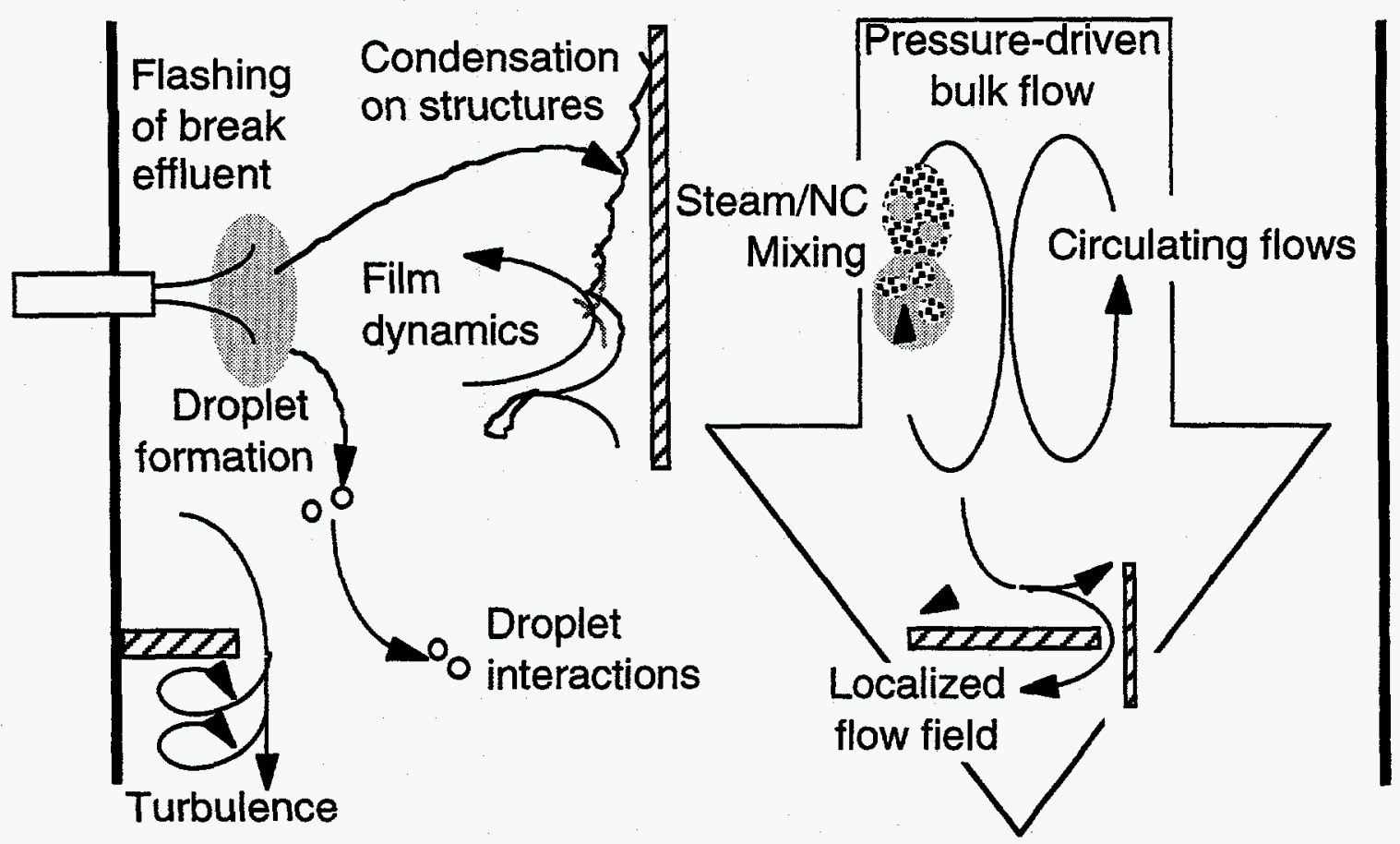

Figure A1. Thermal-hydraulic Pocesses in Drywell Open Areas -- Blowdown Phase --

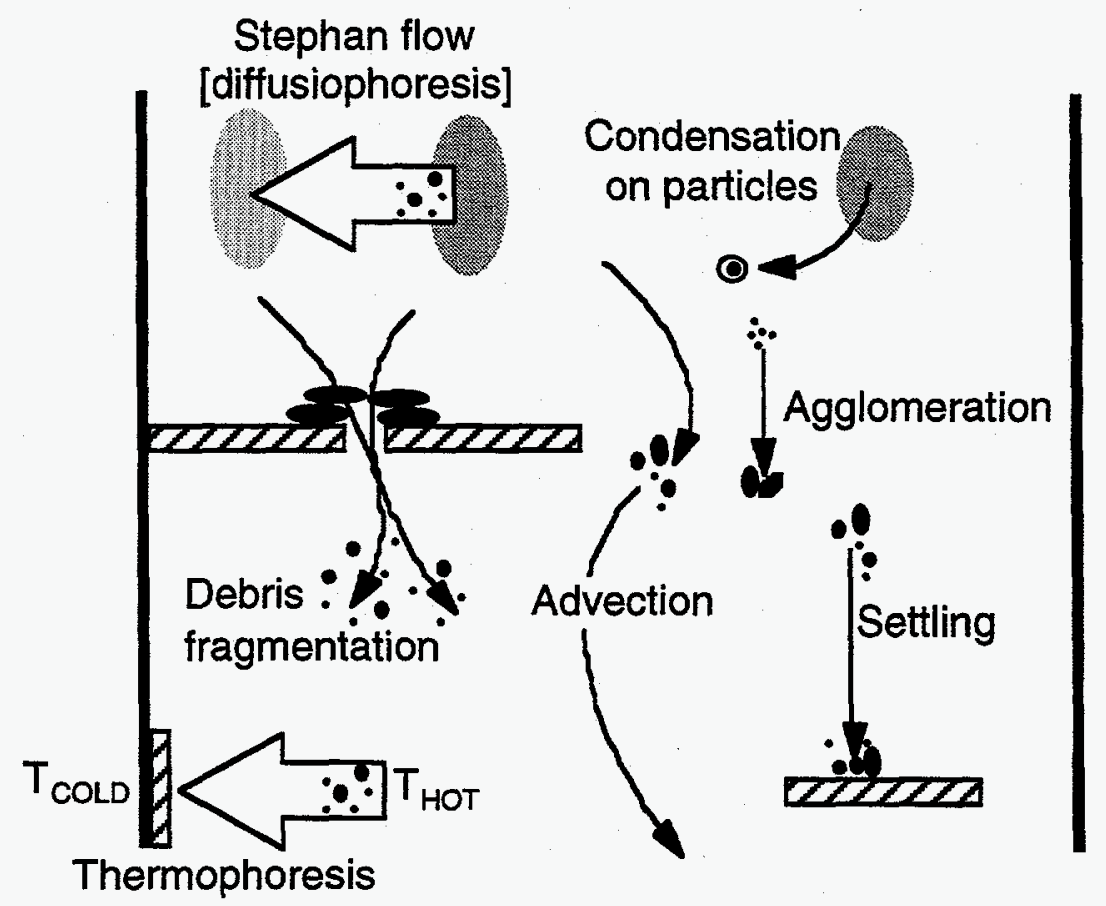

Figure A2. Transport / Deposition Processes for Debris in Drywell Open Areas -- Blowdown Phase -- 


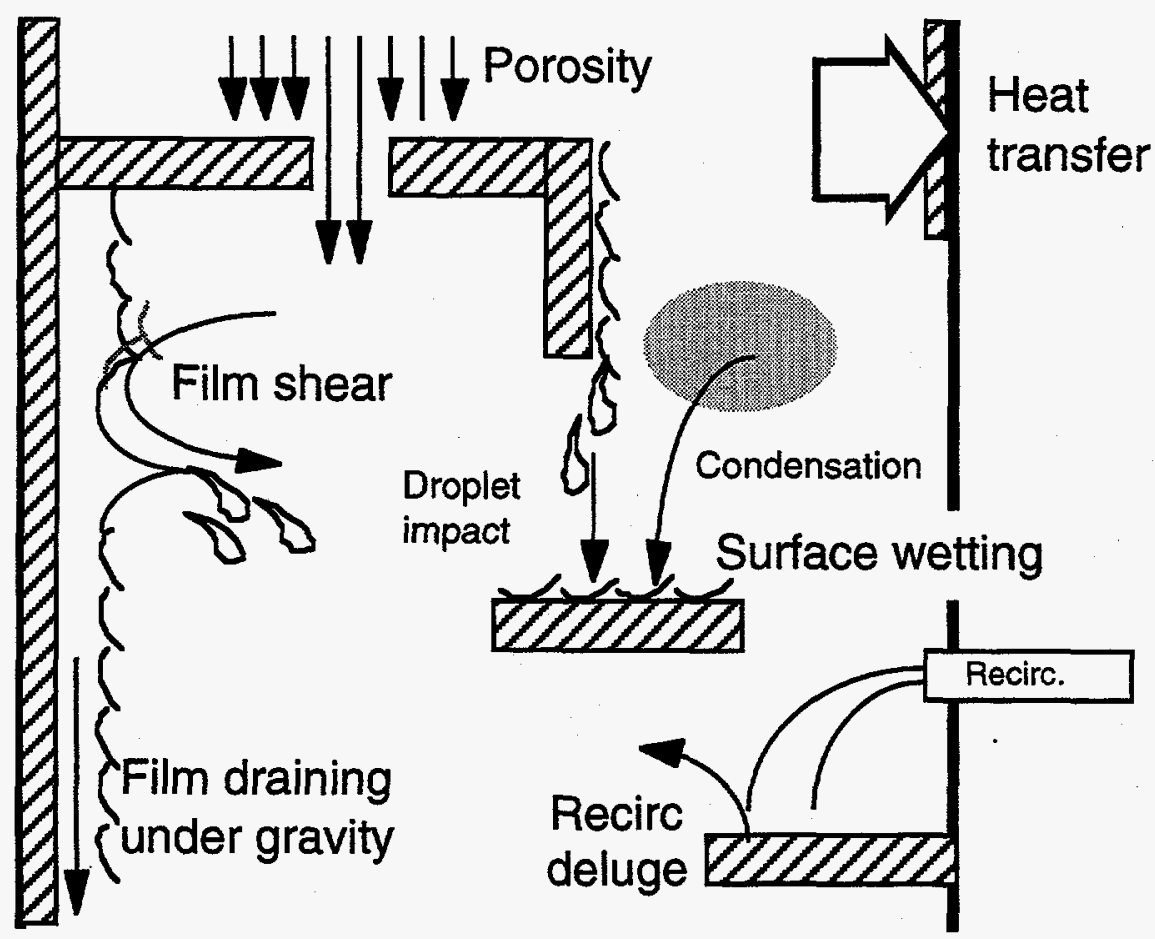

Figure A3. Thermal-hydraulic Processes on Drywell Structures -- Blowdown Phase --

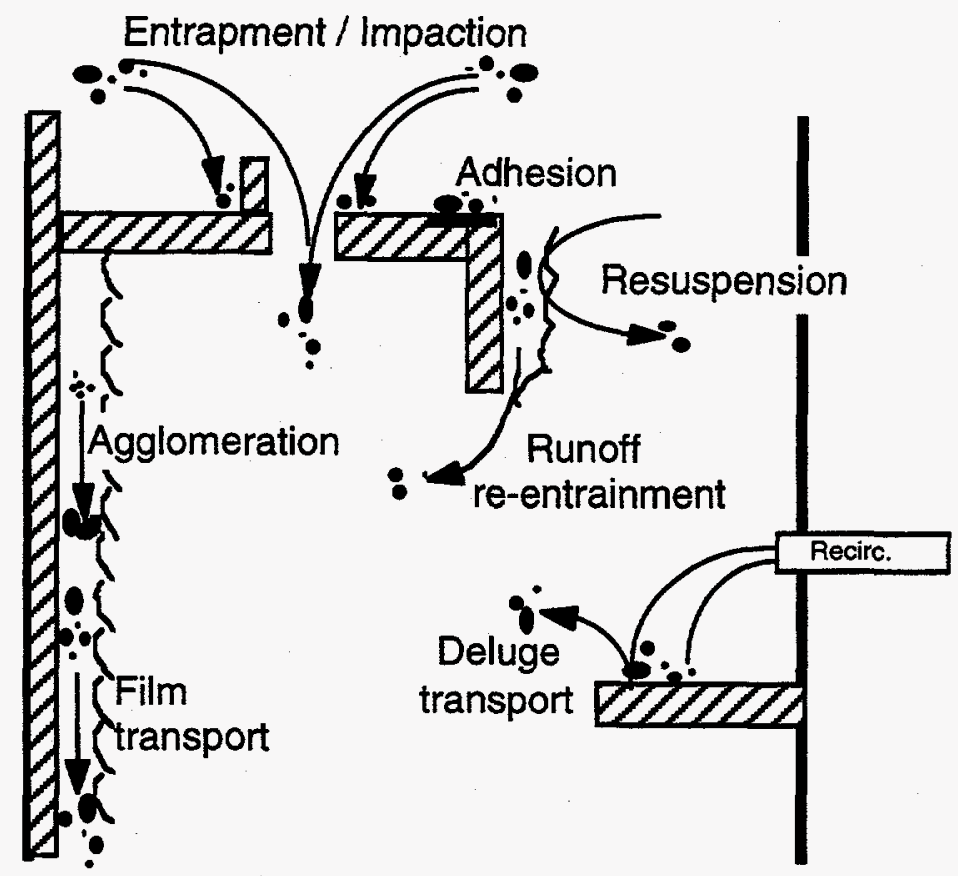

Figure A4. Transport / Deposition Processes for Debris on Drywell Structures -- Blowdown Phase -. 


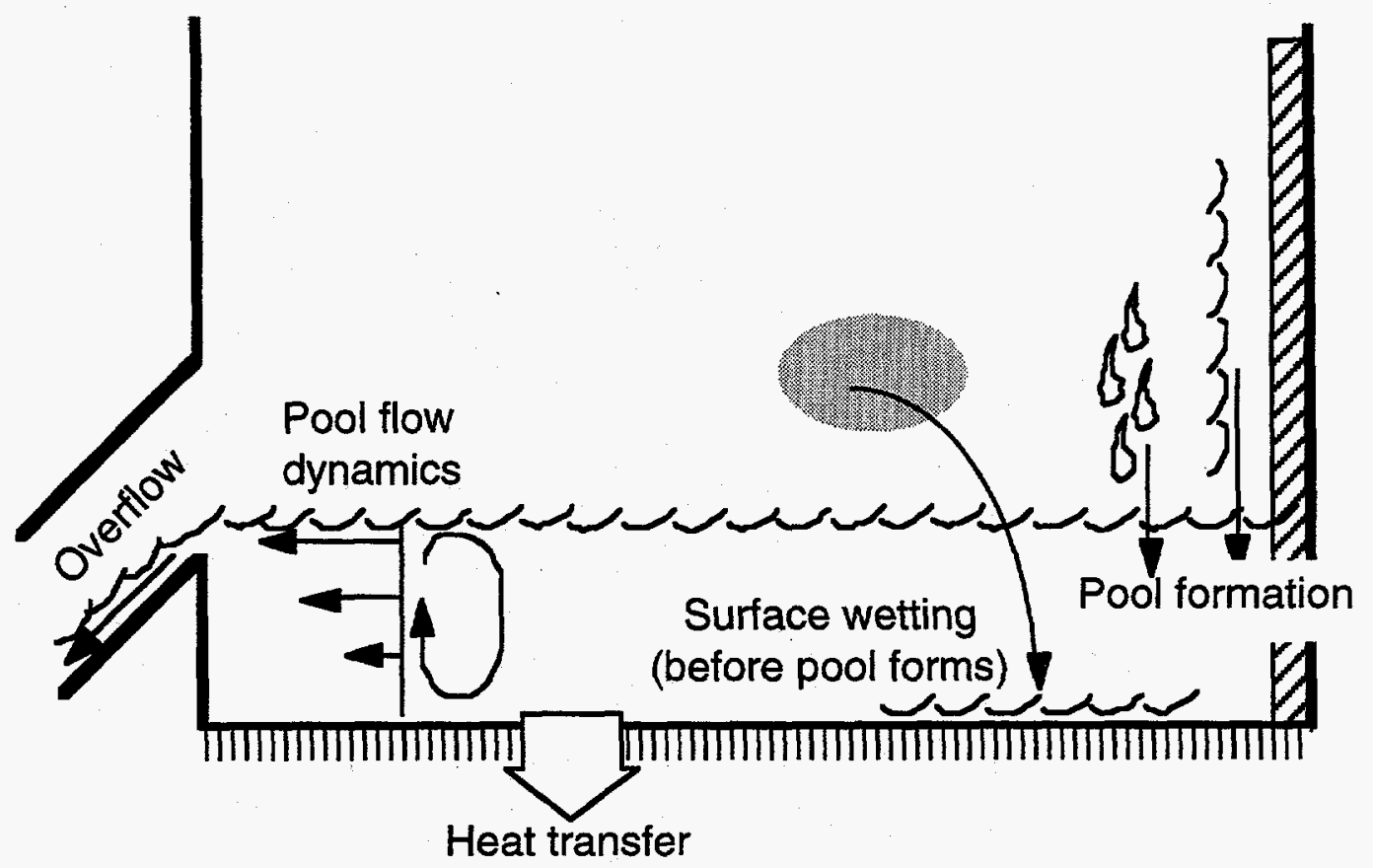

Figure A5. Thermal-hydraulic Processes on the Drywell floor -- Blowdown Phase --

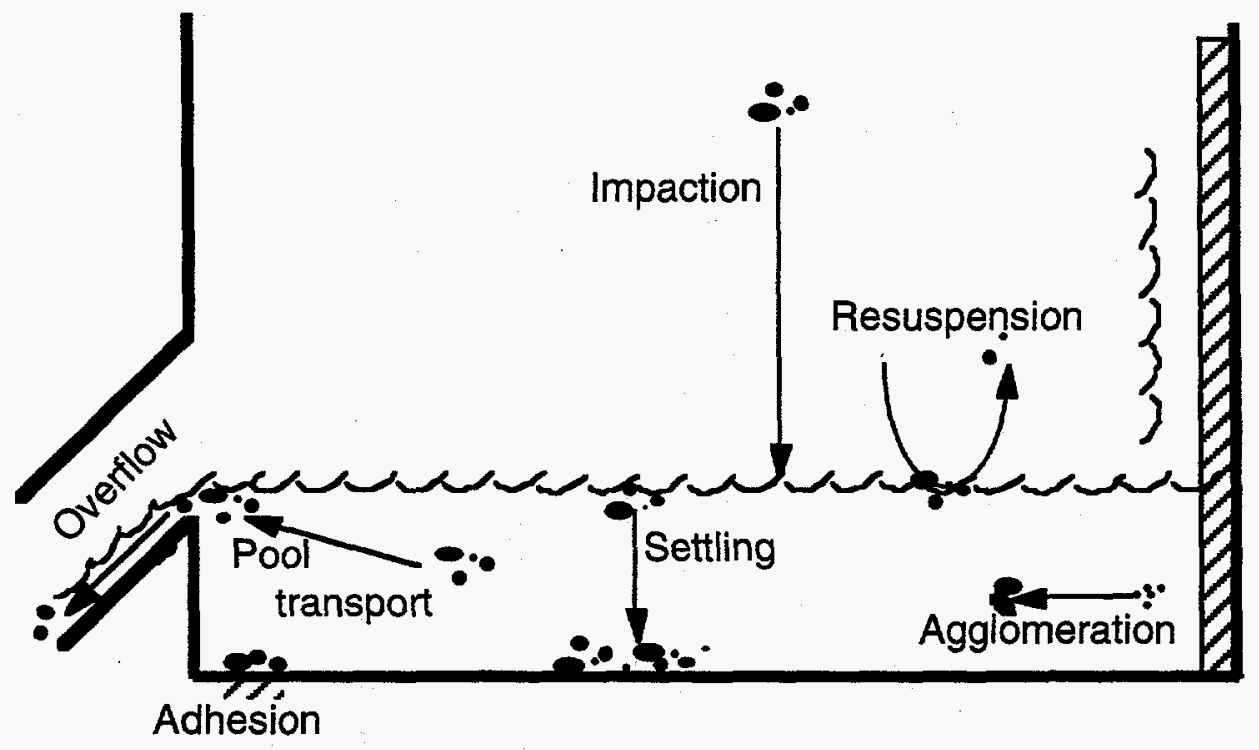

Figure A6. Transport / Deposition Processes for Debris on the Drywell floor -- Blowdown Phase -- 
Table A2. Phenomena descriptions for BWR debris transport post-blowdown phase PIRT (1 of 3) (Reference number relates to entry in Table 2 in the report main body)

\begin{tabular}{|c|c|c|c|}
\hline $\begin{array}{l}\text { Reference } \\
\text { Number }\end{array}$ & Phenomena & Phenomena Description & $\begin{array}{c}\text { See } \\
\text { Figure }\end{array}$ \\
\hline 48 & Pressure reduction due to condensation & Drywell pressure reduction due to reduction in vapor volume fraction. & A7 \\
\hline 49 & Mixed convection flow. & Mixed forced and gravity induced flow. & A1 \\
\hline 50 & Natural circulation & Localized flow driven by buoyancy forces. & A1 \\
\hline 51 & Thermal stratification & Formation of vertical temperature gradient. & \\
\hline$\overline{52}$ & Steam-air distribution (species separation) & Flow patterns promoting species separation. & \\
\hline 53 & Mixing & Similar to Ref. No. 2, Table A1. & \\
\hline$\overline{54}$ & Plume & Centralized local flow pattern. & \\
\hline 55 & Diffusion & Migration due to localized phenomena. & \\
\hline 56 & Spray-induced turbulence & Local fluid vortexes or flow eddies created by spray interactions. & A1 \\
\hline 57 & Liquid transport & Movement of liquid by forced and gravity induced forces. & \\
\hline 58 & Flow regime & Flow field with standardized attributes. & \\
\hline 59 & Spray source & Effects of spray source configuration and attributes. & \\
\hline 60 & Debris advection/slip & Similar to Ref. No. 10, Table A1. & \\
\hline 61 & Stephan flow (diffuseophoresis) & Similar to Ref. No. 16 , Table A1. & \\
\hline 62 & Thermophoresis & Similar to Ref. No. 17, Table A1. & \\
\hline 63 & Debris T-H interactions (both directions) & Similar to Ref. No. 12, Table A1. & \\
\hline 64 & Gravitational settling & Similar to Ref. No. 14, Table A1. & \\
\hline 65 & Removal by airborne liquid & Capture by airborne liquid. & \\
\hline 66 & $\begin{array}{l}\text { Condensation on particles (growth, change } \\
\text { in characteristic) }\end{array}$ & Similar to Ref. No. 15 , Table A1. & \\
\hline 67 & $\begin{array}{l}\text { Agglomeration (growth, change in } \\
\text { characteristics) }\end{array}$ & Similar to Ref. No. 11, Table A1. & \\
\hline 68 & Condensation & $\begin{array}{l}\text { Phase transformation (vapor } \Rightarrow \text { liquid) as steam cools during its } \\
\text { motion through the drywell atmosphere (on structures and suspended } \\
\text { particles). }\end{array}$ & A7 \\
\hline 69 & Film draining under gravity & $\begin{array}{l}\text { Downward, free-surface flow of liquid (water) films on structure } \\
\text { surfaces by gravity. }\end{array}$ & $\overline{A 7}$ \\
\hline 70 & Film shear & $\begin{array}{l}\text { The interfacial interaction between gas flow in the drywell atmosphere } \\
\text { and liquid (condensate) films on structure surfaces. }\end{array}$ & $\overline{\mathrm{A} 7}$ \\
\hline 71 & ECCS deluge & Large flow rate of liquid effluent from ECCS onto drywell structures. & $\overline{\mathrm{A} 7}$ \\
\hline
\end{tabular}


Table A2. Phenomena descriptions for BWR debris transport post-blowdown phase PIRT ( 2 of 3 )




Table A2. Phenomena descriptions for BWR debris transport post-blowdown phase PIRT ( 3 of 3 )

\begin{tabular}{|c|c|c|c|}
\hline $\begin{array}{l}\text { Reference } \\
\text { Number }\end{array}$ & Phenomena & Phenomena Description & $\begin{array}{c}\text { See } \\
\text { Figure }\end{array}$ \\
\hline$\overline{85}$ & $\overline{\text { Settling }}$ & $\begin{array}{l}\text { Downward relocation (sedimentation) of debris within the pool of } \\
\text { water on the drywell floor under the force of gravity. }\end{array}$ & \\
\hline 86 & Impaction & $\begin{array}{l}\text { Capture of debris on the surface of the drywell floor pool due to } \\
\text { inertial impaction. }\end{array}$ & N/A \\
\hline 87 & Resuspension into drywell open area & $\begin{array}{l}\text { Re-entrainment of debris into the atmospheric flow stream from the } \\
\text { drywell floor due to high shear forces at the surface of the floor. }\end{array}$ & $\mathrm{N} / \mathrm{A}$ \\
\hline 88 & Agglomeration & $\begin{array}{l}\text { Mechanical interaction among debris particles on the drywell floor by } \\
\text { which two or more small particles combine to form a larger } \\
\text { conglomerate particle. }\end{array}$ & A9 \\
\hline 89 & Debris fragmentation & $\begin{array}{l}\text { Break up of relatively large pieces of debris on the drywell floor (pool } \\
\text { surface) into smaller particles due to inertial impact of liquid break } \\
\text { effluent from a recirculation line break. }\end{array}$ & A9 \\
\hline 90 & Pressure-driven flow (bulk) & Similar to Ref. No's. $1 \& 42$, Table A1. & \\
\hline$\overline{91}$ & Localized vapor flow field & Similar to Ref. No's. 3 \& 43, Table A1. & \\
\hline 92 & Advected liquid mass & Similar to Ref. No's. $10 \& 45$, Table A1. & \\
\hline$\overline{93}$ & Localized liquid flow field & Similar to Ref. No's. $3 \& 44$, Table A1. & \\
\hline 94 & Advected mass & Similar to Ref. No's. $10 \& 45$, Table A1. & \\
\hline 95 & Entrainment & Similar to Ref. No. 46, Table A1. & \\
\hline 96 & Deleted from final PIRT & & \\
\hline
\end{tabular}




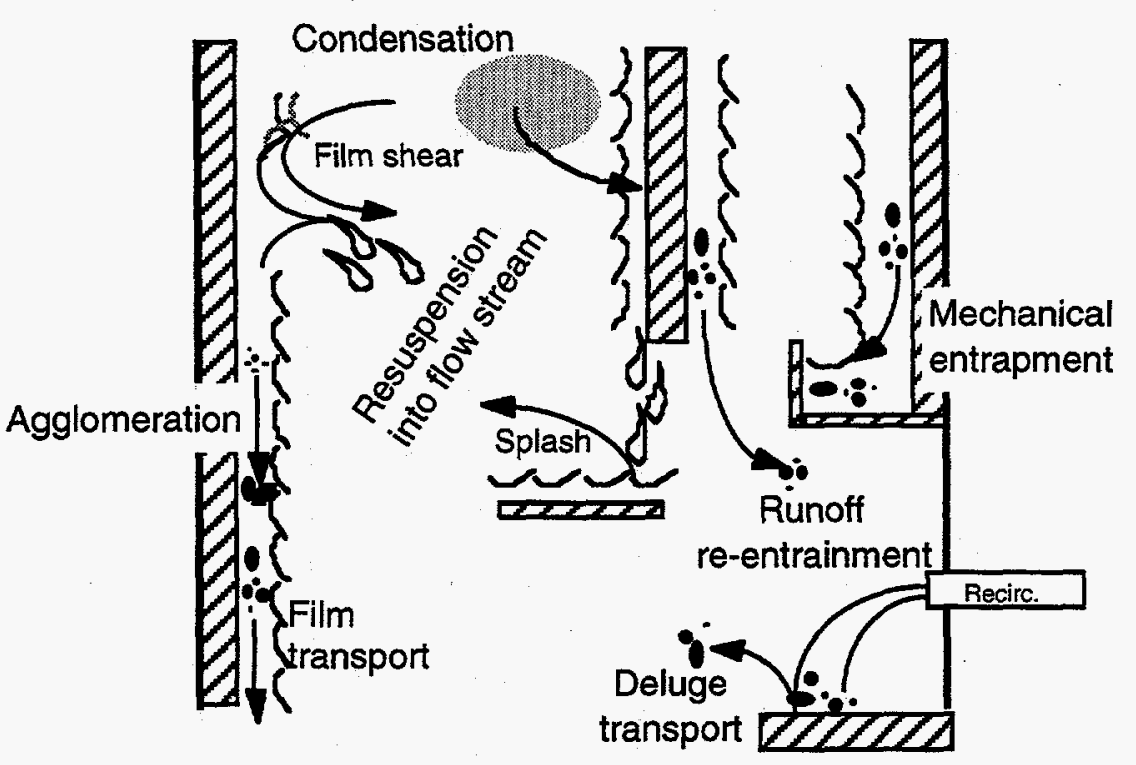

Figure A7. Thermal-hydraulic \& Debris Transport / Deposition Processes on Drywell Structures

-- Post-blowdown Phase --

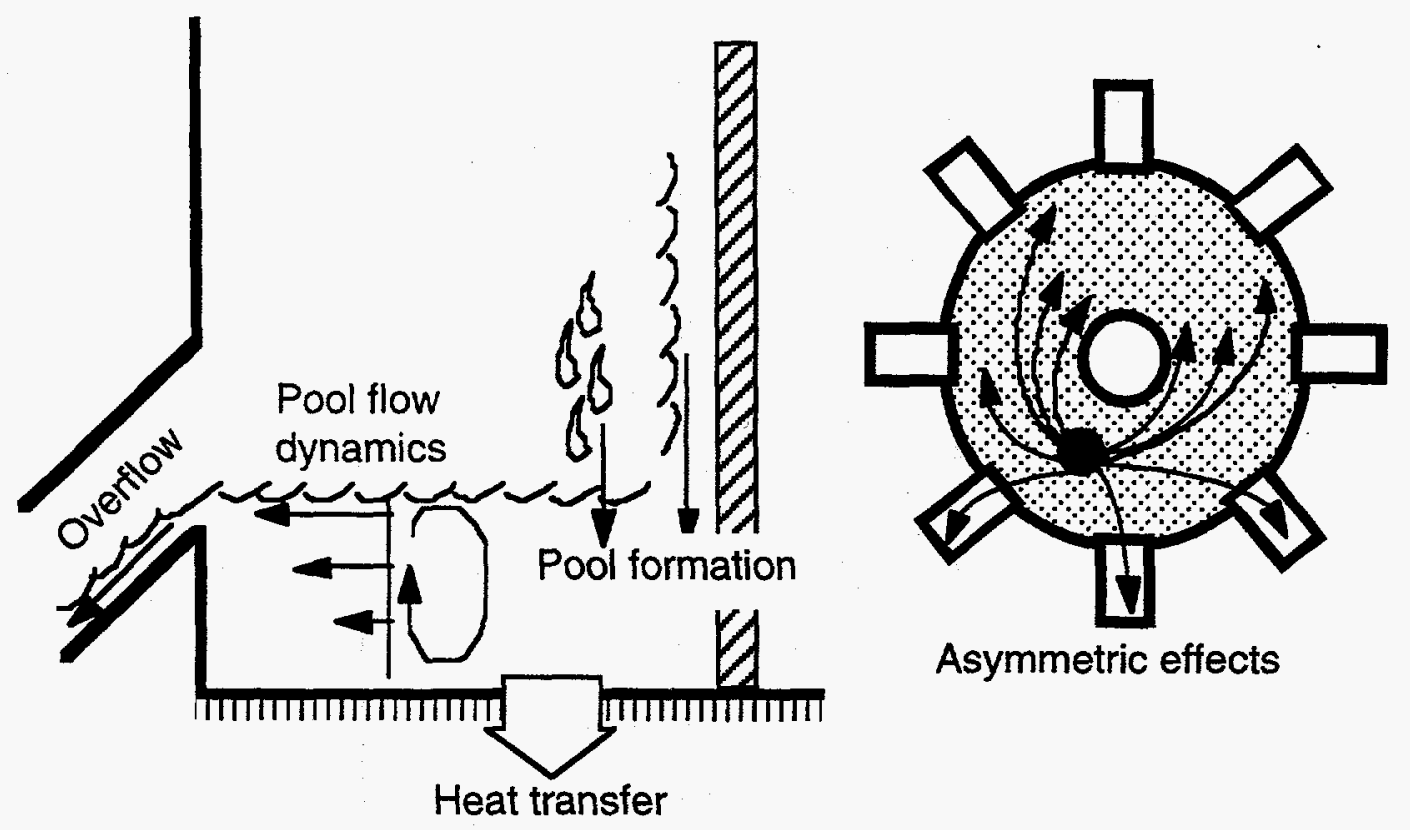

Figure A8. Thermal-hydraulic Processes on the Drywell floor -- Post-blowdown Phase -- 


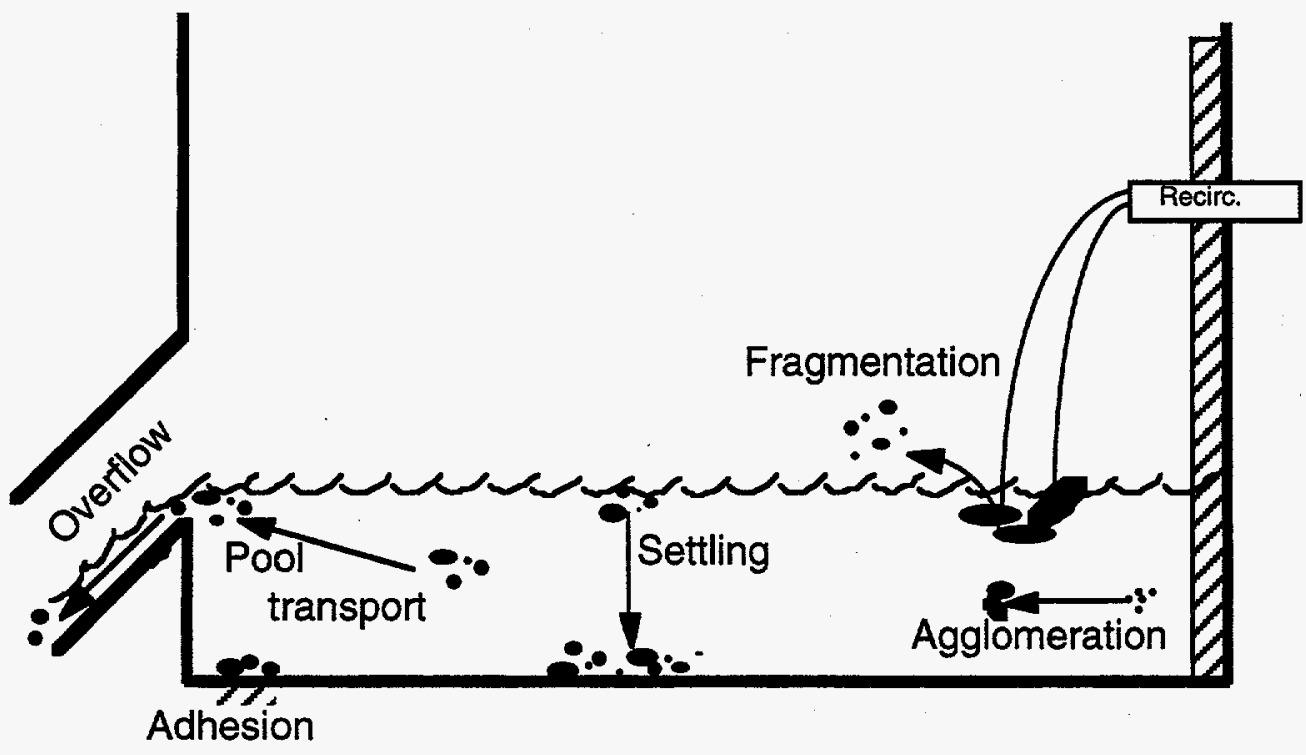

Figure A9. Transport / Deposition Processes for Debris on the Drywell floor -- Post-blowdown Phase -- 
Appendix B:

Ranking Rationales for BWR Debris Transport PIRTs 
Table B1. Ranking rationales for BWR debris transport blowdown phase PIRT ( 1 of 2 )

(Reference number relates to entry in Table 1 in the report main body)

\begin{tabular}{|c|c|c|}
\hline $\begin{array}{l}\text { Reference } \\
\text { Number }\end{array}$ & Phenomena & Ranking Rationale \\
\hline 1 & Pressure driven flows (bulk flows) & $\begin{array}{l}\text { The dominant transport medium for all debris that reaches the wet well. CFD } \\
\text { calculations (Williams for } 0.6 \mathrm{~s} \text { of MSLB, Ref. C29) show large fraction of } \\
\text { drywell free volume is in unidirectional flow. }\end{array}$ \\
\hline 2 & Mixing (noncondensibles) & $\begin{array}{l}\text { Only significant influence is effect on steam condensation, which during } \\
60 \mathrm{~s} \text { blowdown is relatively small. Jet thermal mixing is not controlling bulk } \\
\text { flow. }\end{array}$ \\
\hline 3 & Localized flow field & $\begin{array}{l}\text { Most significant debris depletion mechanism (impaction). The new } \\
\text { experimental evidence strengthened the high rank because of the exhibited } \\
\text { localized flow field mechanism for "smalls" debris avoidance of impaction } \\
\text { and, thus, total transport to wetwell. Break orientation has significant } \\
\text { potential influence on impaction. }\end{array}$ \\
\hline 4 & Turbulence & An effect of channeling, thus of lower order importance. \\
\hline 5 & Flashing of break liquid effluent & $\begin{array}{l}\text { Relates to amount of liquid exiting break. Low for MSLB; (high for } \\
\text { recirculation line break). }\end{array}$ \\
\hline 6 & Droplet interactions & $\begin{array}{l}\text { Assumes w/o spray. Does not significantly affect debris transport because } \\
\text { does not influence the bulk flow field. }\end{array}$ \\
\hline 7 & Condensation (droplet formation) & $\begin{array}{l}\text { No significant condensation in open area (excluding break boundary region). } \\
\text { This is free stream condensation associated with the rapid depressurization. } \\
\text { For the MSLB, it was assumed that the droplet formation occurred within the } \\
\text { source cell of approximately } 10 \mathrm{~m}^{3} \text {. }\end{array}$ \\
\hline 8 & Condensation (structural) & $\begin{array}{l}\text { Of low importance to } \mathrm{T} / \mathrm{H} \text { behavior in open area because the volume of steam } \\
\text { condensing is small compared to an open area volume. }\end{array}$ \\
\hline 9 & Advection/slip & $\begin{array}{l}\text { Dominant debris transport mechanism (correlates with pressure driven and } \\
\text { localized flow fields). }\end{array}$ \\
\hline 10 & Agglomeration & Low rank is based on overall new evidence, including the experiments. \\
\hline 11 & Debris/Flow field coupling & Debris density is too low to result in significant feedback effect. \\
\hline 12 & Debris fragmentation & $\begin{array}{l}\text { (a) Outside of break localized region, significant further breakup not } \\
\text { experimentally observed. (b) Dynamic mechanical processes (i.e., } \\
\text { weedeater, cutting tools) required to produce debris for experiments is } \\
\text { unlikely to be duplicated in NPP. }\end{array}$ \\
\hline 13 & Gravitational settling & $\begin{array}{l}\text { New experimental evidence indicates gravitational induced path vector is } \\
\text { secondary to flow induce path vector. }\end{array}$ \\
\hline 14 & Condensation on particles & Low rank is based on overall new evidence, including the experiments. \\
\hline
\end{tabular}


Table B1. Ranking rationales for BWR debris transport blowdown phase PIRT (2 of 2)

\begin{tabular}{|c|c|c|}
\hline $\begin{array}{l}\text { Reference } \\
\text { Number }\end{array}$ & Phenomena & Ranking Rationale \\
\hline$\overline{15}$ & $\begin{array}{l}\text { Stephan flow (diffuseophoresis) \& } \\
\text { Thermophoresis }\end{array}$ & Insignificant to debris transport in this phase. \\
\hline 16 & Heat transfer & $\begin{array}{l}\text { Moderate-order effect on debris transport because of influence on } \\
\text { containment depressurization. Diminishes the peak pressure (driving } \\
\text { potential) for the flow to the wetwell but the effect is moderate. }\end{array}$ \\
\hline 17 & Film shear & Velocity not high enough to produce significant shear. \\
\hline 18 & Surface wetting (condensation, impact) & High rank is based on overall new evidence, including the experiments. \\
\hline 19 & Film draining under gravity & Low rank is based on overall new evidence, including the experiments. \\
\hline 20 & Recirculation (streaming) deluge & $\begin{array}{l}\text { Deluge of liquid considered to be insignificant during MSLB. (One of the } \\
\text { dominant mechanisms (with vapor/gas transport) of debris during the } \\
\text { recirculation line break.) }\end{array}$ \\
\hline 21 & Resuspension & Low rank is based on overall new evidence, including the experiments. \\
\hline 22 & Agglomeration & Lower order effect (i.e., debris growth vs. direct removal). \\
\hline 23 & Runoff/reentrainment & $\begin{array}{l}\text { New experimental evidence indicates this is not a significant contributor to } \\
\text { airborne debris mass during this time phase. }\end{array}$ \\
\hline 24 & Entrapment/impaction \& Adhesion & Dominant mechanism for removing high-speed airborne debris. \\
\hline 25 & $\begin{array}{l}\text { Pool formation, Pool overflow (timing } \\
\text { issue this phase), Pool flow dynamics, } \\
\text { Pool transport (to/through vent), } \\
\text { Agglomeration in pool \& Settling }\end{array}$ & $\begin{array}{l}\text { Pool formation and its effects considered to be insignificant during the } \\
\text { MSLB. (In the recirculation line break, drywell floor is of equal importance } \\
\text { to drywell open area and structures; however, only if pool forms and then } \\
\text { overflows to vent. Pool dynamics affecting debris settling or suspension is } \\
\text { important to debris transport to the vent.) }\end{array}$ \\
\hline 26 & Heat transfer to structure & Importance to surface wetting. \\
\hline 27 & $\begin{array}{l}\text { Surface wetting (before pool formation), } \\
\text { Adhesion \& Impaction }\end{array}$ & $\begin{array}{l}\text { For the MSLB, experimental evidence indicates drywell floor is not a } \\
\text { significant contributor to debris transport behavior during blowdown. The } \\
\text { "smalls" were transported regardless. The medium, large and "canvassed" } \\
\text { debris amounts below the bottom grate are not significant to total amount of } \\
\text { debris. }\end{array}$ \\
\hline 28 & Resuspension & Importance related to likelihood in context of low free stream velocity. \\
\hline 29 & $\begin{array}{l}\text { Pressure driven flow (bulk) (vapor/gas), } \\
\text { Localized vapor \& liquid flow fields, } \\
\text { Advected mass, De-entrainment \& } \\
\text { Re-entrainment }\end{array}$ & $\begin{array}{l}\text { a) Mark I \& II: Component is of overall less importance to debris transport } \\
\text { than other components because essentially all debris arriving at component is } \\
\text { transported to the drywell. This conclusion applies only to the Mark I and II } \\
\text { containments. } \\
\text { b) This conclusion may not apply to the Mark III, therefore, in the final PIRT } \\
\text { the rank was increased to moderate importance. }\end{array}$ \\
\hline
\end{tabular}


Table B2. Ranking rationales for BWR debris transport post-blowdown phase PIRT (1 of 1 )

(Reference number relates to entry in Table 2 in the report main body)

\begin{tabular}{|c|c|c|}
\hline $\begin{array}{l}\text { Reference } \\
\text { Number }\end{array}$ & Phenomena & Ranking Rationale \\
\hline 30 & $\begin{array}{l}\text { All referenced phenomena listed under the } \\
\text { drywell open area component in Table } 2 \text { in } \\
\text { the report main body }\end{array}$ & $\begin{array}{l}\text { Assigned rank for this component is } 2 \text { because airborne debris during this } \\
\text { phase is negligible. See drywell turnover figure showing about } 7 \text { turnovers } \\
\text { during the blowdown phase. An important related factor of this component } \\
\text { assignment is that no process/phenomena will have a rank higher than the } \\
\text { component rank. }\end{array}$ \\
\hline 31 & $\begin{array}{l}\text { Condensation, Film draining under gravity, } \\
\text { Film related transport, and } \\
\text { Runoff/re-entrainment }\end{array}$ & Low rank is based on overall new evidence, including the experiments. \\
\hline 32 & Film shear & Moderate contributor to resuspension. \\
\hline 33 & ECCS deluge & $\begin{array}{l}\text { New experimental evidence, related to washdown/erosion, indicates } \\
\text { phenomenon is significant to debris transport. }\end{array}$ \\
\hline$\overline{34}$ & Re-suspension into flow stream & Only important in fast draining films which already transport debris. \\
\hline 35 & Mechanical entrapment & Low rank is based on overall new evidence, including the experiments. \\
\hline 36 & Heat transfer to structure & Low rank is based on overall new evidence, including the experiments. \\
\hline 37 & Pool overflow & Dominant mechanism for debris transport to wetwell. \\
\hline 38 & Asymmetric effects & Low potential to significantly affect amount of debris transported to wetwell. \\
\hline 39 & $\begin{array}{l}\text { Pool formation \& Localized liquid flow } \\
\text { field }\end{array}$ & $\begin{array}{l}\text { Considered improbable for MSLB, but (moderate to high contributor to } \\
\text { debris transport to wetwell in the recirculation line break). }\end{array}$ \\
\hline 40 & $\begin{array}{l}\text { Pool flow dynamics \& Pool transport } \\
\text { (to/toward vent) }\end{array}$ & $\begin{array}{l}\text { Relates to fraction of debris available for overflow transport. Significant } \\
\text { pool formation and overflow effects considered improbable for MSLB, but } \\
\text { (can be significant for recirculation line break). }\end{array}$ \\
\hline 41 & Settling & Major contributor to pool entrapment of debris. \\
\hline$\overline{42}$ & Debris fragmentation & $\begin{array}{l}\text { New experimental evidence indicates continued fragmentation is insignificant } \\
\text { in both transients. }\end{array}$ \\
\hline 43 & Pressure-driven flow (bulk) & Very little suspended debris in gas/vapor field; low vapor velocity. \\
\hline$\overline{44}$ & Advected liquid mass & Only contribution is by runoff from structures. \\
\hline 45 & Advected mass & $\begin{array}{l}\text { Relates to potential of flow conditions to carry over debris to wetwell. } \\
\text { Considered improbable for the MSLB, and (moderate for the recirculation } \\
\text { line break). }\end{array}$ \\
\hline
\end{tabular}


Appendix C:

Information Base Used in the Application of the PIRT Process to Debris Transport in a BWR Drywell 
Documents associated with the first PIRT meeting

C1 W. W. Durgin and J. Noreika, The Susceptibility of Fibrous Insulation Pillows to Debris Formation Under Exposure to Energetic Jet Flows, NUREG/CR-3170, Alden Research Laboratory (March 1983).

C2 Kevin W. Brinckman, Results of Hydraulic Tests on ECCS Strainer Blockage and Material Transport in a BWR Suppression Pool, EC-059-1006, Revision 0 (May 1994).

C3 SEA, A Methodology for Estimating BWR Drywell Transport Fractions During Blowdown and Washdown, SEA N0. 93-554-06-A:12, Science And Engineering Associates, Inc. (July 1995).

C5 Aleck W. Serkiz et al., An Overview of the BWR ECCS Strainer Blockage Issues, NUREG/CR-0149, Volume 3, Brookhaven National Laboratory (March 1996) pp 175-199.

C6 George E. Hecker et al., Experiments of ECCS Strainer Blockage and Debris Settling in Suppression Pools, NUREG/CR-0149, Volume 3, Brookhaven National Laboratory (March 1996) pp201-225.

C7 Gilbert L. Zigler and D. V. Rao, The Strainer Blockage Assessment Methodology Used in the BLOCKAGE Code, NUREG/CR-0149, Volume 3, Brookhaven National Laboratory (March 1996) pp227-235.

C8 D. V. Rao et al., Proposed Methodology for Modeling LOCA Debris Transport in BWR Drywells, Science And Engineering Associates, Inc. (February 5, 1996).

C9 G. E. Wilson, Statistically Based Uncertainty Analysis for Ranking of Component Importance in the Thermal Hydraulic Safety Analysis of the Advanced Neutron Source Reactor, EGG-NE-10078, EG\&G Idaho, Inc. (1992).

C10 T. Saaty, Decision-Making For Leaders, Belmont, CA, Lifetime Learning Publications, Wadsworth Inc. (1982).

C11 Gilbert L. Zigler, NUREG/CR-6224 Overview, Science and Engineering Associates (April 1996).

C12 Clint Shaffer, Overview of Proposed Analytical Methods for Addressing Debris Transport Problem, Science and Engineering Associates (April 16, 1996).

C13 George Hecker, Why Use CFD For Drywell Transport?, Alden Research Laboratory (April 1996).

C14 D. V. Rao, Phenomenological Considerations in Drywell Debris Transport, Science and Engineering Associates (April 16-18, 1996).

C15 Gary E. Wilson, PIRT Process Considerations, Idaho National Engineering Laboratory (April 1996).

C16 Letter Report: First Meeting Approved Minutes For BWR Debris Transport PIRT, Gary E. Wilson to Aleck Serkiz, transmitted by GEW-12-96 (5/20/96).

\section{Documents associated with the second PIRT meeting}

C17 D. V. Rao et al., Drywell Debris Transport Methodology: Responses to PIRT Panel Request for Information, SEA No. 96-3104-06-A:1, Science And Engineering Associates, Inc. (May 1996).

C18 D. V. Rao, Accident Progression Scenarios for BWR, Science And Engineering Associates, Inc. (May 1996).

C19 D. V. Rao et al., SEAVARL Proposed Methodology for Important Phenomena Identified by PIRT Panel, Science And Engineering Associates, Inc. (May 1996).

C20 Mark Leonard, Basic Information on Non-Spherical Particle Transport Properties, Innovative Technology Solutions Corp. (May 1996).

C21 John E. Brockmann, Aerosol Physics, Sandia National Laboratories (May 1996).

C22 Lothar Wolf and Mark Leonard, Collection of Schematics Describing Important Physical Phenomena for Debris Transport in BWR Containment During and After LOCA, University of Maryland and Innovative Technology Solutions Corp. (May 1996). 
C23 Lothar Wolf, Description of Coupled Thermohydraulics and Aerosol Phenomena in LWR Containment, University of Maryland (May 1996).

C24 Lothar Wolf, Suggestions for Dimensionless Presentations of Major Aerosol Transport Processes in LWR Containments, University of Maryland (May 1996).

C25 Lothar Wolf, Overview of Experimental and Analytical Results of Containment LOCA and Aerosol Behaviors, University of Maryland (May 1996).

C26 Lothar Wolf, Summary of Unpublished German Experiments on Insulation Damages and Floating Behavior, University of Maryland (May 1996).

C27 K. Mun and L. Wolf, GOTHIC Computation and Comparisons with Data of Marviken (BWR) Test 17, University of Maryland (May 1996).

C28 K Mun and L. Wolf, GOTHIC Computation of BWR Mark I LOCA with Spray Operation, University of Maryland (May 1996).

C29 Ken A. Williams, CFD Simulation of BWR Drywell Response to MSLB Event, Flow Simulation Services, Inc. (May 15, 1996).

C30 Mark Leonard, Insights from Some Quick MELCOR Calculations, Innovative Technology Solutions Corp. (May 1996).

C31 Eric Haskin and Francisco Souto, Sensitivity Analysis Approach Proposed for Debris Drywell Transport Study, University of New Mexico and Science And Engineering Associates, Inc. (May 1996).

C32 Letter Report: Transmittal Of Initial BWR Debris Transport PIRT, Gary E. Wilson to Aleck Serkiz, transmitted by GEW-14-96 (6/27/96).

Documents associated with the PIRT panel review/evaluation of experimental program

C33 D. V. Rao et al., Drywell Debris Transport Study, Draft Phase 1 Letter Report, SEA 96-3105-010-A:2 (September 27, 1996).

C34 Letter Report: Transmittal Of BWR Debris Transport PIRT Panel Review Of SEA Experimental Plan, Gary E. Wilson to Aleck Serkiz, transmitted by GEW-47-96 (11/15/96).

C35 D. V. Rao, D. Cremer, B. Carpenter, and K. Weingardt, "Drywell Debris Transport Testing Program Review/Planning," Science \& Engineering Associates, Inc. presentation (January 28, 1997).

C36 C. Shaffer, "Reconciliation and Integration of Experimental Data and Analyses," Science \& Engineering Associates, Inc. presentation (January 28, 1997).

C37 Letter Report: January 28-29, 1997, Drywell Task Program Review and Planning Meeting, Brent E. Boyack to Gary E. Wilson, transmitted by TSA-10-97-158 (2/10/98).

C38 Phillip S. Stacy et al., Experimental Evaluation of Inertial Debris Capture on BWR Drywell Structures Following a LOCA (Draft), ARL (April 1997).

C39 D. V. Rao et al., Experimental Study of Erosion of Insulation Debris by Recirculating ECCS Flow Following a LOCA, Letter Report SEA 97-3105-A:7, SEA (May 20, 1997).

C40 D. V. Rao et al., Drywell Debris Transport Testing CEESI Test Program: Description and Results, Presentation Handout SEA 97-3105-A:8, SEA (May 21, 1997).

C41 Clint Shaffer, Drywell Floor Pool CFD Calculations, Presentation Handout SEA 97-3105-A:9, SEA (May 21, 1997).

C42 Clint Shaffer et al., Debris Transport Study: Deductions and Quantification, Presentation Handout SEA 97-3105-A:10 Revision 1, SEA (June 5, 1997).

C43 Clint Shaffer, Debris Transport Study: Quantification Results and Logic Charts, Presentation Handout SEA 97-3105-A:11, SEA (June 5, 1997).

C44 D. V. Rao, LOCA Debris Transportability in the Drywell Floor Pool: Interpretation of ARL/PPL Flume Transport Data, Letter Report SEA 97-3105-A:12, SEA (May 20, 1997).

C43 D. V. Rao, Drywell Debris Transport Study: Program Outline and Milestones, Presentation Handout SEA 97-3105-A:13, SEA (May 21, 1997). 